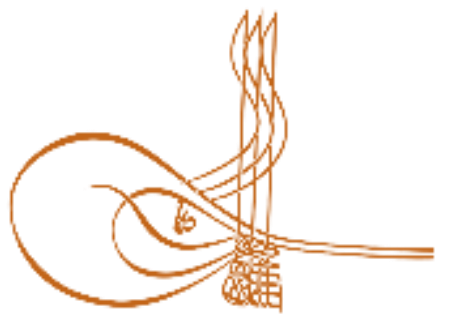

www.turkishstudies.net/turkishstudies
Turkish Studies

eISSN: $1308-2140$

Research Article / Araştırma Makalesi

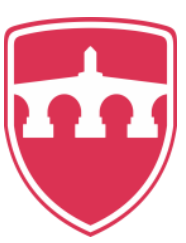

INTERNATIONAL

BALKAN

UNIVERSITY

Sponsored by IBU

\title{
Suzidilara Makamının Tarifler ve Bestelenen Eserler Açısından İncelenmesi
}

Analysis of Suzidilara Maqam in Terms of Recipes and Composed Works

\author{
Mehmet Ali Esen* - Alkan Akınci*
}

\begin{abstract}
The description of the Suzidilara maqam is first made by Abdulbâkî Nasır Dede in his book Tedkîk ü Tahkîk. Nasır Dede, explained that III. Selim invented Suzidilara maqam. Since Dede did not clearly indicate the scale or scales that made up the Suzidilara maqam in his description, many theorists use different compound scales when describing that maqam.

In this study, it is aimed to find out the compatibility between the scales and characteristics of the Suzidilara maqam which are determined by the analysis of 52 pieces composed by different composers, and ten different theorists' description of this maqam. To compare composers' usage of scale or scales in their compositions in Suzidilara maqam, and the scale or scales in the descriptions of Suzidilara maqam, forms the basis of this study. Therefore, the differences between the 10 theorists' descriptions of Suzidilara maqam were examined in this study. Then, instrumental pieces composed in the Suzidilara maqam: 11 peşrev, 1 medhal, $11 \mathrm{saz}$ semaisi and vocal works: 1 mevlevi ayini, 1 ilahi, 2 teşvih, 2 ağır semai, 4 yürük semai, 1 murabba beste, 1 beste 17 şark1 total of 52 works, were analyzed by the modal analysis method. Composers' usage of the Suzidilara maqam and the scales in their works were determined in 52 works. 10 theorists who made the description of the Suzidilara maqam and 32 composers who composed in Suzidilara maqam were presented in historical order.
\end{abstract}

Structured Abstract: Introduction 18. during the century, Abdulbaki Nasır Dede became one of the pioneers of the traditional Turkish music innovation movement with his work Tedkik ü Tahkik (Truth research and investigation) and explained his views on makam and makam descriptions in the edvars written in ancient times. Dede, describes 14 maqam and 136 compound in his research work. Nasır Dede, Safiyüddin and Meragi described the 12 main makams Büzürk, Zengüle and Zirefkend makams instead of Segah, Saba, Nişabur, Nihavend and of III. Selim added his to the Suzidilara maqam, which is thought to be the composition, increasing the number of maqams from 12 to 14 (Tura, 2006: 17). Providing extensive information on the Turkish music theory (Doğrusöz and Uruş 2012: 429). Nasır Dede has to say about Suzidilara: authority that

\footnotetext{
* Öğretmen, MEB

Teacher, Ministry of National Education

ORCID 0000-0002-6037-9708

memedaliesen@gmail.com

** Dr. Öğr. Üyesi, Van Yüzüncü Yıl Üniversitesi, Türk Müziği Devlet Konservatuvarı, Geleneksel Türk Müziği Bölümü Asst. Prof. Van Yuzuncu Yil University, Turkish Music State Conservatory, Department of Classical Turkish Music ORCID 0000-0002-1314-1086

alkanakinci@gmail.com

Cite as/ Atıf: Esen, M. A., Akıncı, A. (2020). Suzidilara makamının tarifler ve bestelenen eserler açısından incelenmesi, Turkish Studies, 15(2), 973-998. https://dx.doi.org/10.29228/TurkishStudies.40264

Received/Geliş: 23 December/Arallk 2019

Accepted/Kabul: 25 April/Nisan 2020

Copyright $\subset$ MDE, Turkey

Checked by plagiarism software

Published/Yayın: 30 April/Nisan 2020

CC BY-NC 4.0
} 
decorates the World, trick the source of the river, the head of the owners of knowledge and skills (our king) one of the inventions peace forgiving human spirit, a gift of appreciation is a happy pod (Tura,2006:38). III. Selim did not reveal a pure sequence when he created his Suzidilara maqam, he may have assembled several makam sequences, or he may have revived an old forgotten ink maqam (Koç, 2011: 93). Yakup Fikret Kutluğ, the of Suzidilara maqam, The view that it was known before the period of III. Selim. İt did not gain certainty, and that the works in hand that contradict this view, He stated that there is no illuminating document that it was composed before III. Selim (Kutluğ, 2000: 304).

Purpose: In this study, the series and characteristics of Suzidilara maqam determined by the analysis of 52 works composed by different composers and the ways in which ten different theorists describe this maqam relate to each other and reveal the level of overlap.

\section{Result}

\section{Results For The First Sub-Problem}

In this study, the descriptions of 10 theorists who reported their views on the Suzidilara maqam were examined and as a result of this examination, it was determined that there were three main views on the use of sequences in the Suzidilara maqam recipe. These views are the theorists who express views on the axis of the composition of Çargah and Mahur, the theorists who express views on the axis of the composition of Nigar and Büzürk, and the theorists who express views on the axis of the composition of Rast, Buselik and Hüseyni. Although these views are not completely overlapping, it has been seen that these insights are close in the other sequences and descriptions that come together with the basic sequence.

Theorists who express views on the axis of composition of Çargah and Mahur

Theorists such as Onur Akdoğu, Erol Sayan and Ahmet Selim Teymur, who supported his opinion with Hüseyin Sadeddin Arel, interpreted the description of the Maqam as follows; the Maqam of Suzidilara was created by mixing the Çargah maqam of Rast into the Çargah maqam of the place. Ismail Hakkı Özkan, while describing the makam series, commented on Arel's views. Suzidilara maqam says that the consists of Do major and left major in Western music and that the hangings are La minor, Mi minor, Fa major and Re minor. There are differences between the works composed in maqam and this understanding. Because the sequence of Çargah maqam was not used prominently in the works. Although the Mahur maqam sequence is often used in the makam series, The Uşşak condiment and the Buselik maqam sequence in the Hüseyni curtain are also frequently used. There is a structure resembling the Büzürk maqam sequence.

Theorists who express views on the axis of Nigar and Büzürk composition

Dr. Suphi Ezgi points out that Suzidilara maqam is the continuation of Büzürk and Nigar maqam. Sultan III. Selim Works composed before the period of support this view. This view is close to the researcher Nail Yavuzoğlu, Büzürk and Suzidilara maqam from Nigar expressed that the sequence of Suzidilara maqam Nigar, Mahur and Buselik maqam came together. Yakup Fikret Kutluğ stated that the makam series was formed by the coming together of Nigar, Mahur and Hüseyni maqam sequences and expressed a close view of Ezgi's maqam description. As a result of the maqamal analysis of the works, it is seen that the sequences that make up the maqam coincide with this view. When describing the series of Kutluğ Hüseyni series instead of Hüseyni maqam series, Hüseyni maqam defines the treble region.

Theorists who express views on the axis of Rast, Buselik and Hüseyni composition

Ekrem Karadeniz and Gülçin Yahya Kaçar describe the Suzidilara maqam sequence as follows; it was formed by the coming together of Rast, Buselik and Hüseyni maqams. The series of Rast maqam was almost never used except for one work when the works were examined. Cinuçen Tanrikorur 1 work was composed with the series Rast maqam. The Uşşak quartet was frequently used in the series of Buselik maqam and Hüseyni curtain.

\section{Results For The Second Sub-Problem}

The study examined 52 works. As a result of this examination, the composition of Nigar, Büzürk and Buselik, Büzürk and Buselik composition, Mahur and Buselik composition Mahur and Rast composition Rast and Huseyni composition and Mahur and Çargah composition sequence were used in the formation of Suzidilara maqam. 
Composers using Nigar, Büzürk and Buselik sequences are Gazi Giray Han and Kantemiroğlu. When the 4 works written in suzidilara maqam with this understanding are examined, the result is as follows; the maqams that make up the Suzidilara series are Nigar, Büzürk and Buselik. It has been observed that the sequence of Suzidilara maqam is formed by a combination of these maqam sequences.

The composers using the Büzürk and Buselik sequences are Raftar Kalfa, Bülbüloğlu, Seyit Ahmet Ağa, Dellalzade, Selim Dede, Nayi Raşit Efendi, Alaeddin Yavaşça, Şehzade Abdullah and Manok Ağa. 13 (thirteen) works are given in this conception. When the works composed in Suzidilara maqam were examined, the result of the series forming the Maqam is as follows; the Suzidilara maqam series was formed when the Büzürk and Buselik maqam series came together.

Composers using Mahur, Büzürk and Buselik maqam sequences; Sultan III. Selim, Sultan Mehmet Vahdettin, Zekai Dede, Hafiz Mehmet Efendi, Muallim Ismail Hakkı Bey, Fethi Karamahmudoğlu and Sultan II. Mahmut. 18 (eighteen) works have been given in this conception. According to these composers, the way the maqam is rendered and its use is as follows; it has been interpreted that the Suzidilara maqam sequence occurs when the Mahur, Büzürk and Buselik maqam sequences come together.

Composers using Mahur and Buselik sequences are Arapzade, Kemani Riza Efendi, Cemil Bey, Udi Hasan Bey, Necdet Varol, Akın Özkan and Sitkı Sahil. 7 (seven) works are given in this understanding. According to these composers, it was formed by the combination of Mahur and Buselik maqam which formed the sequence of Suzidilara maqam.

The composer using Rast and Hüseyni maqam sequences is Cinuçen Tanrıkorur. 1 (one) works are given in this understanding. When the composer's work is examined, it is seen that the Suzidilara maqam series is formed by the combination of the Rast and Hüseyni maqam series.

Composer using Mahur and Çargah maqam sequences; Erol Sayan, Şeref Çakar, Varujan Zilciyan, Sadettin Çevik, Hüsnü Üstün and Yalçın Mıhçı by composers 7 (seven) works were given to Suzidilara maqam. These composers seem to reflect Arel's understanding.

Keywords: III. Selim, Suzidilara, Scale, Maqam, Compound

Öz: Suzidilara makamının tarifi ilk olarak Abdulbaki Nasır Dede tarafından Tedkîk ü Tahkik adlı eserinde yapılmaktadır. Nasır Dede, Suzidilara makamının III. Selim'in buluşu olduğunu belirtmektedir. Dede, Suzidilara makamı tarifinde makamı oluşturan dizi veya dizileri net olarak belirtmediğinden ötürü birçok kuramcı Suzidilara makamını tarif ederken farklı bileşik diziler kullanmaktadıllar. Bu çalışmada, farklı besteciler tarafindan bestelenen 52 adet eserin analizi sonucu belirlenen Suzidilara makamı dizi ve özellikleri ile on farklı kuramcının bu makamı tarif etme biçimlerinin birbiriyle ilişkilendirilip ne düzeyde örtüştügünün ortaya çıkarılması amaçlanmaktadır. Suzidilara makamının tariflerdeki dizi veya diziler ile makamda bestelenmiş olan eserlerde bestekârların diziyi nasıl kullandıklarıyla ilgili karşılaştırma makalenin temelini oluşturmaktadır. Bu sebeple çalışmada, Suzidilara makamı tarifi yapan 10 kuramcının ortaya koymuş oldukları tariflerin farklılıkları incelenmiştir. Sonrasında Suzidilara makamında bestelenen saz eseri olarak: 11 peşrev, 1 medhal, 11 saz semaisi ve sözlü eser olarak: 1 mevlevi ayini, 1 ilahi, 2 teşvih, 2 ağır semai, 4 yürük semai, 1 murabba beste, 1 beste 17 şarkı olmak üzere toplamda 52 adet eser makamsal analiz yöntemiyle incelenmiştir. Makamsal analizi yapılan 52 adet eserde bestekârların Suzidilara makamını nasıl kullandıkları ve eserlerde kullanılan diziler saptanmıştır. Suzidilara makamının tarifini yapan 10 kuramcı ve Suzidilara makamında eser veren 32 bestekârlar geçmişten günümüze sıralanarak sunulmuştur.

Anahtar Kelimeler: III. Selim, Suzidilara, Dizi, Makam, Terkip

\section{Giriş}

13. yüzyıl sonlarında Safiyüddîn Abdülmümin Urmevî’nin başlattığı nazari çalışmalar Geleneksel Türk müziğinin temelini oluşturmaktadır. Urmevî'den 50-70 yıl sonra Abdulkadir Merâgî, müzik tarihine önemli derecede katkısı olan dört büyük kitabını yayınlamanın yanısıra Urmevî'nin Kitabü'l Edvar (Devirler Kitabı) adlı eserini şerh ederek zincirin (Sistemci Okul) ikinci halkası olmuştur (Elinç, 2005: 3). Safiyüddîn'in matematiksel temele dayandırdığı diziler Merâgî 
tarafından makam olarak kullanmış ve makam kelimesini dile getiren ilk müzik bilgini olmuştur (Tura, 2017: 158). Ardından 18. yüzyılda Abdulbaki Nasır Dede, yazdığı Tedkîk ü Tahkik (Hakikati Araştırma ve Soruşturma) adlı eser ile Geleneksel Türk müziği yenilik hareketinin öncülerinden olmuş ve eski dönemlerde yazılmış edvarlarda geçen makam ve makam tarifleriyle ilgili görüşlerini açıklamıştır. Dede Tedkîk ü Tahkik eserinde 14 makam ve 136 terkibi tarif etmektedir. Nasır Dede, Safiyüddîn ve Merâgî'nin tarif ettiği 12 ana makamdan Büzürk, Zengüle ve Zirefkend makamlarını çıkararak yerine Segâh, Sabâ, Nişabur, Nihâvend ve III. Selim'in terkibi olduğu düşünülen Suzidilara makamını ekleyerek ana makam sayısını 12'den 14'e çıkarmıştır (Tura, 2006: 17). Türk müziği nazariyatı üzerine de geniş bilgi veren (Doğrusöz ve Uruş 2012: 429) Nasır Dede Suzidilara makamı hakkında şöyle demektedir: Cihanı süsleyen bu makam, bir hüner nehrinin kaynağı, bilgi beceri sahiplerinin başı olan (Padişahımızın) insan ruhuna sefa bağışlayan buluşlarından biri, kutlu beğenilerinden bir lütuf goncasıdır (Tura,2006:38). Ancak kaynaklarda Gazi Giray, Kantemiroğlu ve Raftâr Kalfa'nın Suzidilara makamında eserleri bulunmaktadır. Fatih Koç buna atıfta bulunarak III. Selim, Suzidilara makamını oluştururken saf bir dizi ortaya çıkarmamış olup, birkaç makam dizisini bir araya getirerek oluşturduğu ya da eski unutulmuş bir mürekkep makamı yeniden canlandırmış olabileceğini belirtir. (Koç, 2011: 93). Yakup Fikret Kutluğ ise Suzidilara makamının, III. Selim döneminden önce de bilindiği görüşünün kesinlik kazanmadığını, bu görüşe aykırı düşen eldeki eserlerin III. Selim'den önce bestelendiğine dair aydınlatıcı bir belge bulunmadığını ifade etmiştir (Kutluğ, 2000: 304). 20. yüzyılda Arel-Ezgi-Uzdilek ses sistemi içerisinde Çargâh makamının yeniden düzenlenmesiyle nazari olarak etkilenen makamların başında Suzidilara makamı gelmektedir. Günümüzde Çargâh makamının Batı müziğindeki Do majör dizisine karşı1ık gelmesinden dolayı çoğu kaynakta Suzidilara makamı tarifi yapılırken Do majör ve Sol majör ifadeleri kullanılmaktadır. Belirtilen ana dizi tanımlamalarının makam tariflerini önemli derecede etkilediği görülmektedir.

\subsection{Problem Durumu}

18. yy. sonlarında III. Selim tarafından terkip edildiği düşünülen Suzidilara makamı, Abdulbaki Nasır Dede'nin Tedkîk ü Tahkik adlı eserinde ilk tarifi yapılmıştır. Ancak bu tarif yapılırken Suzidilara makamının hangi dizilerden oluştuğuna dair açıklayıcı bilgi bulunmamaktadır. 20. yy'da Hüseyin Saadettin Arel eski Çargâh makamını yeniden düzenlemesiyle tamamen yalın hale getirmiş ve Suzidilara makamını yeni Çargâh makamı dizisi ile tarif etmiştir. Bu iki durum Suzidilara makamının kuramcılar tarafindan farklı yorumlanmasına neden olmuştur.

\subsection{Problem Cümlesi}

Suzidilara makamı tarifini yapan 10 kuramcının ortaya koymuş oldukları tariflerdeki diziler ve Suzidilara makamında bestelenen eserlerdeki diziler arasında farklılıklar var midır?

\subsubsection{Birinci Alt Problem}

Türk müziği kuramcılarının ortaya koymuş oldukları Suzidilara makamının tarifler arasında farklılıklar var mıdır?

\subsection{2. İkinci Alt Problem}

Suzidilara makamında bestelenen eserlerde bestekârlar eserlerinde hangi bileşik dizileri kullanmışlardır?

\subsection{Araştırmanın Amacı}

Bu çalışmada, farklı besteciler tarafından bestelenen 52 adet eserin analizi sonucu belirlenen Suzidilara makamı dizi ve özellikleri ile on farklı kuramcının bu makamı tarif etme biçimlerinin birbiriyle ilişkilendirilip ne düzeyde örtüştügünün ortaya çıkarılması amaçlanmaktadır. 


\subsection{Araştırmanın Önemi}

Suzidilara makamında çeşitli formlarda bestelenmiş toplam 52 adet eserin daha önce herhangi bir çalışmada incelenmemiş olması bu çalışmanın önemini oluşturmaktadır.

\subsection{Saylttılar}

$\mathrm{Bu}$ çalışmada, nota arşivlerinin araştırma için uygun ve yeterli olduğu, çalışmada kullanılacak bilimsel yöntemlerin gerçeği yansıtabileceği varsayılmıştır.

\subsection{Sinırlılıklar}

Araştırma, Türk müziği nazariyat kitaplarında Suzidilara makamı ile ilgili tarifi bulunan on kuramcının görüşleri ve makamda farklı besteciler tarafından bestelenen 52 adet eserin makamsal analizi ile sınırlandırılmıştır.

\section{YÖNTEM}

Bu bölümde araştırmanın modeli, evren ve örneklem, verilerin toplanması, toplanan verilerin işlenmesi ve çözümlenmesinde kullanılan yöntem ve teknikler yer almaktadır.

\subsection{Araştırmanın Modeli}

$\mathrm{Bu}$ araştırmanın literatür taraması aşamasında, nazariyat kitapları, makale, tez ve internet siteleri gibi erişilebilen kaynaklardan yararlanılmıştır. Bu tarama, Suzidilara makamı ile ilgili kuramcı görüşleri, makamın dizisi ve özellikleri hakkında geniş bir inceleme ile yapılmıştır. Çalışmanın betimsel analiz boyutunda on farklı kuramcı tarafından yapılan Suzidilara makamı tarifine ilişkin bulgular, besteciler tarafından bestelenen eserlerin dizi saptanmasında ne derece örtüştüğü, analiz yöntemi kullanılarak bulgulara ve bu araştırmanın amaçlarına uygun olarak yorumlanmıştır.

Tablo 1: Araştırmada İncelenen Formlar

\begin{tabular}{|l|l|}
\hline FORM & ADET \\
\hline Peşrev & 11 \\
\hline Medhal & 1 \\
\hline Saz Semai & 11 \\
\hline Teşvih & 2 \\
\hline Mevlevi Ayin-i Şerif-i & 1 \\
\hline İlahi & 1 \\
\hline Sark1 & 17 \\
\hline Ağır Semai & 2 \\
\hline Yürük Semai & 4 \\
\hline Murabba Beste & 1 \\
\hline Beste & 1 \\
\hline Toplam & 52 \\
\hline
\end{tabular}

Araştırma esnasında yapılan taramalarda Suzidilara makamında toplam 56 eserin bestelendiği saptanmış olup bunlardan 52 eserin makam dizisine ve geleneksel seyir anlayışına uygun olup olmadığı değerlendirilirken diğer 4 eserin ise notasına ulaşılamamıştır. Eserlerin makamsal analizi, temel dörtlü-beşliler ve özel dörtlü-beşliler esas alınarak her bir ölçünün tespiti yapılmıştır. Ezginin, ölçüyü aştığı eserlerde ise birden fazla ölçü birlikte ele alınıp çözümlenmiştir.

\subsection{Evren ve Örneklem}

Çalışmanın evreni, Suzidilara makamı tarifi ve kullanımıdır.

Çalışmanın örneklemi ise Suzidilara makamında bestelenen ve notası bulunan çeşitli formlardaki eserlerdir. 


\subsection{Verilerin Toplanması}

Verilerin toplanmasında tarama yöntemi kullanılmış ve bu yöntem ile Suzidilara makamında bestelenen eserlerin nazariyat kitapları ve internet sitelerinde erişilebilen notalardan faydalanılmıştır.

\subsection{Toplanan Verilerin Analizi}

Çalışmada, eserleri makamsal açıdan küçük parçalara ayırarak eserlerin bestelendiği makamın dizisini oluşturan dörtlü-beşlileri, asma kalış-çeşnileri ve eser içinde başka bir makama yapılan geçkiyi saptamak için makamsal analiz yöntemi kullanılmıştır (Akdoğu, 1996: 127).

$\mathrm{Bu}$ araştırmada Onur Akdoğu'nun makamsal anlayışa ilişkin yaptığı saptamalardan yararlanılmış ve çalışmanın içeriğine uygun aşağıda verilen 4 maddesi referans alınmıştır.

a) Eserin, makamın geleneksel seyir anlayışına uygun olup-olmadığının saptanması.

b) Ezgilerin, geleneksel olup-olmadığının saptanması.

c) Ezgilerin, farklı bestecilerin eserleriyle ya da aynı bestecinin farklı eserleriyle benzerlik taşıyıp taşımadığının saptanması.

d) Eserde; geçki, çeşni ve renk unsurlarının bulunup bulunmadığı, varsa bilinçli ve yerinde yapılıp yapılmadığının saptanması.

\section{Bulgular ve Yorum}

\subsection{Kuramcının Suzidilara Makamı Tarifi}

Çalışmanın bu bölümünde kuramcıların nazariyat kitaplarında yer verdiği Suzidilara makamı tarifleri kronolojik olarak sıralanmış ve Suzidilara makamında eser veren bestekârların eserleri analiz edilerek, bestekârların makamı ele alma biçimleri ve makamı nasıl kullandıklarına dair fikir edinilmiştir. Eserler sadece makamsal açıdan analiz edilmiştir. Nigar ile Büzürk dizisi kullanılan eserlerde Nigar dörtlü ve beşlisi, Mahur dizisi kullanılan eserlerde Çargâh dörtlü ve beşlisi referans alınarak incelenmiştir. Diğer eserlerin makamsal analizinde GTM'de makam dizisini oluşturan ana dörtlü-beşliler ve özel dörtlü-beşliler temel alınarak analiz yapılmıştır. Suzidilara makamında 32 bestekâr tarafından bestelenmiş olan eserlerden tamamının makamsal analizi yapılmıştır. Form olarak saz eserleri:11 Peşrev, 1 Medhal ve 11 Saz Semaisi. Sözlü eserleri: 1 Mevlevi Ayini, 1 İlahi, 2 Teşvih, 2 Ağır Semai, 4 Yürük Semai, 1 Murabba Beste, 1 Beste 17 Şarkı olmak üzere toplamda 52 adet eser incelenmiştir.

\subsubsection{Abdulbaki Nasır Dede'nin Göre Suzidilara Makamı}

Abdülbâki Nasır Dede (1765-1821), Tedkîk ü Tahkik adlı eserinde Suzidilara makamını şöyle tarif etmektedir: Bûselik perdesinden başlayıp Çargâh perdesine çıkar; oradan yine Bûselik’ten Dügâh'a, Rast'a ve Geveşt'e inip ardından Rast perdesi göstererek karar verir. Çargâh'tan yukarı Neva, Hüseyni, Acem, Gerdaniye ve Muhayyer perdesine dek ve Geveşt’ten aşağı Irak, Aşiran ve Yegâh perdesine dek gezinilebilir (Tura, 2006:38).

\subsubsection{Abdulkadir Töre ve Ekrem Karadeniz’e Göre Suzidilara Makamı}

Abdulkadir Töre (1873-1946) ve öğrencisi Ekrem Karadeniz (1904-1981) Suzidilara makamı hakkında şunları dile getirmektedir; Suzidilara makamı Rast çeşnisi ile başlarken, Mâhur makamına geçerek Mâhur ve Hüseyni perdelerini kullanmaktadır. Hüseyni perdesi üzerinde kalış yaparak bu makama özgü çeşniyi meydana getirip yine Rast makamına döner ve Rast perdesinde karar verir. Bu makam Rast, Mahûr ve Hüseyni makam dizilerinin karışık olarak kullanılmasıyla meydana gelmiştir (Karadeniz, 2013: 131). 

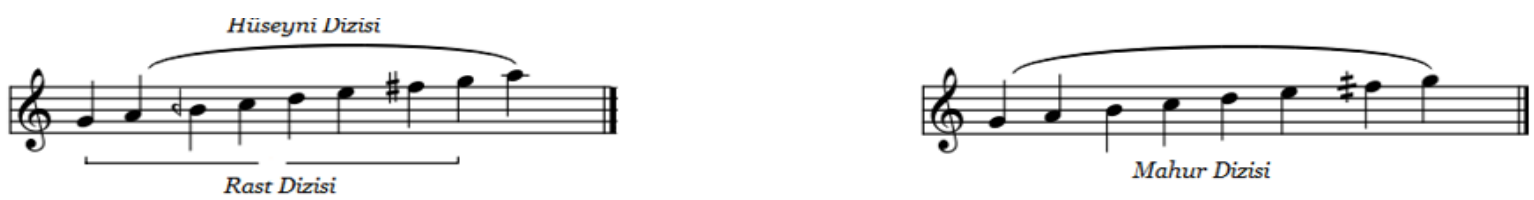

Şekil 2. Hüseyni, Rast ve Mahur Dizisi

Bestelenen eserler incelendiğine, Rast ve Hüseyni makam dizileri çok az kullanılmış olup, çeşni olarak Rast ve Hüseyni sık kullanılmaktadır.

\subsubsection{Dr. Suphi Ezgi'ye göre Suzidilara Makamı}

M. Suphi Ezgi (1869-1962), Büzürk, Suzidilara ve Nigar'ın aynı makamlar olduğunu dile getirmektedir. Aynı makama farklı zamanlarda müzisyenler tarafindan verilen farklı üç isimdir. Bu makamlar kendi mevkilerinde Çargâh dizisine Buselik, Hüseynide Buselik ve Mahur makamı dizisinin birbiriyle karıştırılmasından doğmuştur (Ezgi, 1933: 179).
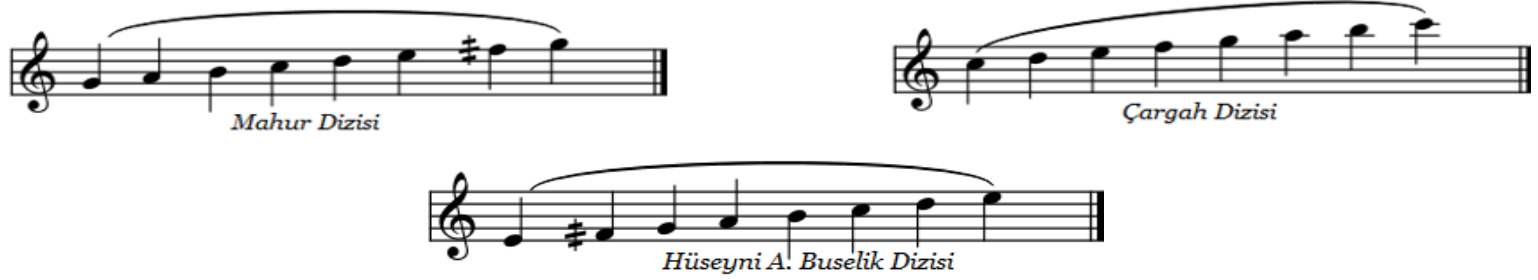

Şekil 3. Mahur, Çargâh ve Buselik Dizisi

\subsubsection{Hüseyin Saadettin Arel'e Göre Suzidilara Makamı}

Hüseyin Saadettin Arel (1880-1955), Onur Akdoğu'nun Türk müziği nazariyat derslerinden derleyerek kitaplaştırdığı "Hüseyin Sâadeddin AREL "Türk Mûsıkîsi Nazariyatı Dersleri” adlı eserinde Suzidilara makamını şöyle tarif eder:

Çargâh makamı ile Mahur makamının (Rast perdesindeki Çargâh makamı) bir arada kullanılmasıyla oluşmuştur. Makamın seyir özelliği inici-çıkıcıdır. Dizi yazılırken donanıma değiştirici işaret yazılmaz değişiklikler ölçü içerisinde yapılır.
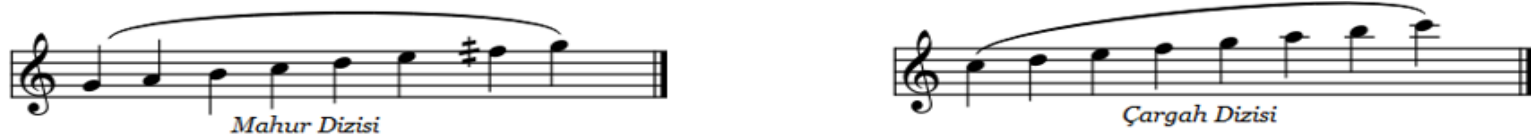

Şekil 4. Mahur ve Çargâh Dizisi

Ayrıca bu makamdan diğer uygun makamlara geçki yapılabileceğini ifade etmektedir (Akdoğu, 1993: 273).

\subsubsection{Ahmet Selim Teymur'a Göre Suzidilara Makamı}

Ahmet Selim Teymur (1923-1985), "Türk Mûsikisi” adlı kitabında Suzidilara makamını şöyle tarif etmiştir; Adı Farsça gönül süsleyen ateş anlamına gelmektedir. Nigâr adıyla bilinen aynı birleşim zamanla unutulmuştur. 1800'lü yıllarda III. Selim tarafından yeniden terkip edilmiştir. Rast kararlı birleşik makamlardandır. Çargâh makamı dizisiyle, Mahur (Rast perdesindeki Çargâh) makamı dizisinin birlikte kullanılmasıyla oluşmuştur (Teymur, 2010: 202).
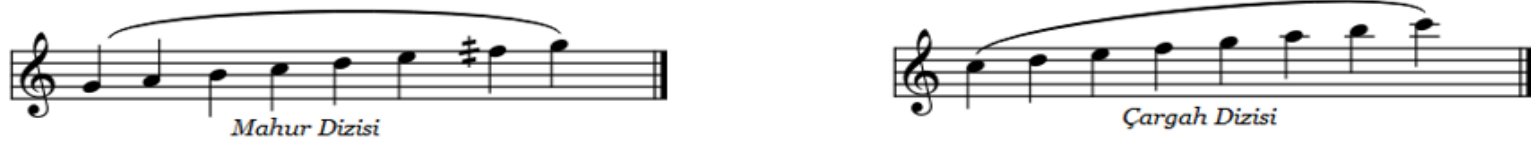

Şekil 5. Mahur ve Çargâh Dizisi 


\subsubsection{Erol Sayan'a Göre Suzidilara Makamı}

Erol Sayan'ın (1936- -) Suzidilara makamı tarifi şöyledir: Çağdaş (Çargâh) makamı dizisi ile Mahur makamı dizisinden meydana gelmiştir. Güçlüleri, Çağdaş perdesi, Hüseyni perdesi ve Neva perdesidir. Donanımı Mahur perdesidir. Eserlerden gözlemlediğimiz kadarı ile Rast perdesinden seyre başladığımız gibi diğer perdelerden de başlanılabilir. Çargâh ve Hüseyni perdeleri güçlü ve geçici güçlü gibi kullanarak seyir yapılabilir. Bazı eserlerde, geçki olarak Nikriz ve Hicaz makamları kullanılmıştır. Neva perdesinden karara gidilirken Segâh perdesinin kullanılmasıyla Rast beşlisi oluşur, bu durumda makamın Çargâh beşlisi ile karar verilmesini doğru bulmayan Sayan bu durumu "Böyle tehlikeli durumlardan bestecinin ustalıkla kaçacağını tahmin ediyorum" şeklinde ifade etmiştir (Sayan, 2010: 141).
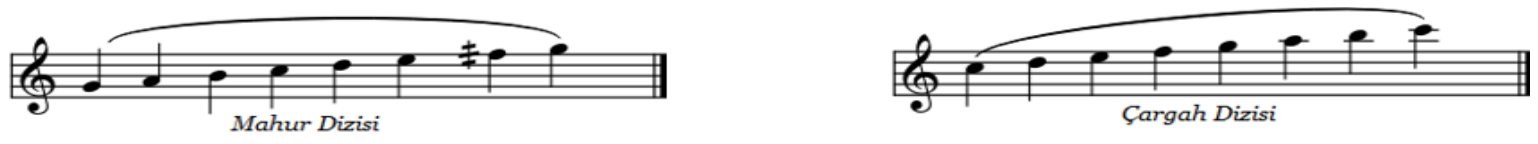

Şekil 9. Çargâh ve Mahur Dizisi

\subsection{7. İsmail Hakkı Özkan ‘a Göre Suzidilara Makamı}

İsmail Hakkı Özkan (1941-2010) Suzidilara makamını şöyle tarif etmektedir: Durağı Rast perdesidir. Çıkıcı, inici-çıkıcı olarak kullanılmaktadır. Çargâh perdesindeki Çargâh makamı dizisine Rast perdesindeki Çargâh makamı dizisinin eklenmesiyle meydana gelmektedir. Güçlü perdesi bazen Çargâh bazen Neva perdesi olarak kullanılmıştır. Asma karar perdeleri Suzidilara makamının ana yapısını oluşturan Çargâh'ta ve Rast'da olmak üzere iki Çargâh makamı dizisinden meydana gelmiştir (Özkan, 2000: 425-426-427).
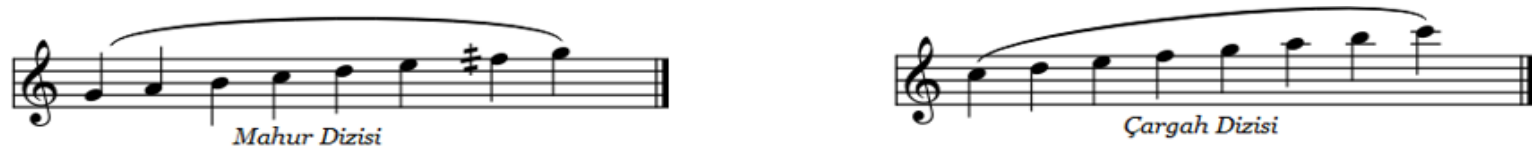

Şekil 6. Mahur ve Çargâh Dizisi

\subsubsection{Yakup Fikret Kutluğ 'a Göre Suzidilara Makamı}

Yakup Fikret Kutluğ, Arel ve Ezgi’nin görüşüne katılmadığını ifade ederek nedenini bu makamların dizi ve çeşnilerinin farklı olmaları şeklinde belirtmiştir.

Suzidilara makamı çıkıcı bir seyir gösterir. Üç makamın bir araya gelmesinden meydana gelmiştir. Bu makamlar; Nigar, Mahur ve Hüseyni makamlarıdır. Mahur makamı, Nigar ve Hüseyni makamından daha az kullanılır seyrin içerisinde zaman zaman gösterilir. Suzidilara makamında bestekârlarımızın geçici geçki olarak kullandıkları yerinde Hicaz ve Nikriz makamları ise makamın dizisinde yer almayan ilave makamlardır (Kutluğ, 2000: 305).
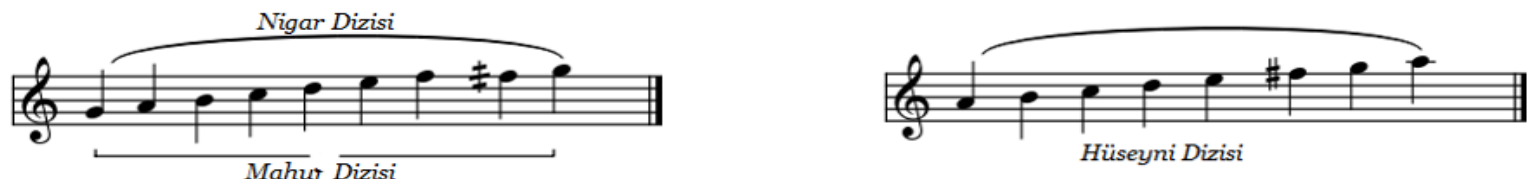

Şekil 7. Nigar, Mahur ve Hüseyni Dizisi

\subsubsection{Nail Yavuzoğlu'na Göre Suzidilara Makamı}

Nail Yavuzoğlu (1960- -), Suzidilara makamını şöyle tarif eder: Suzidilara makamının ana iskeletini oluşturan Mahur, Bûselik, Nikriz ve Hicaz dizilerini gösteren Nigâr makamıdır. Mahur Nigâr 4'lüsünün 5'liye dönüşmesiyle oluşur. Nigâr'ın II. derecesinde Bûselik dizisi doğal olarak oluşmaktadır. Bu makamda temel dizi Nigâr makamı dizisidir. Mahur, Bûselik ve Nikriz makamlarına geçki yapıldığına dikkat çekmektedir (Yavuzoğlu, 2011:65). 


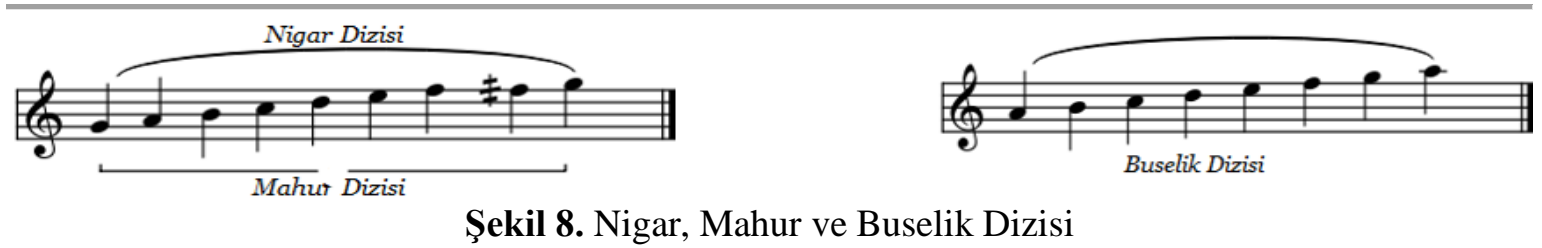

\subsubsection{Gülçin Yahya Kaçar’a Göre Suzidilara Makamı}

Gülçin Yahya Kaçar (1966- -) Suzidilara makamı şöyle tarif eder: Makam Rast, Bûselik ve Hüseynî makamlarının bir araya gelmesinden oluşmuştur. Makamın durağı Rast perdesi, makamın güçlüsü Neva perdesi, yedeni ise Irak perdesidir. Makamın donanımında değiştirici işaret bulunmaz, gerekli değiştirici işaretler ölçü içerisinde gösterilir. Makam Yegâh perdesi üzerinde Rast dörtlüsüyle genişlemektedir (Kaçar, 2009: 258-259).
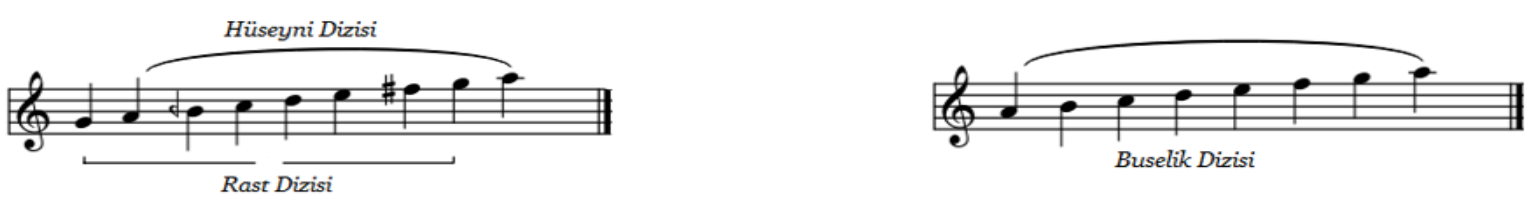

Şekil 1. Hüseyni, Rast ve Buselik Dizisi

\subsection{Eserlerin Makamsal Analizi}

\subsubsection{Gazi Giray Han'ın “Suzidilara Saz Semaisi”" Adlı Eseri}

Gazi Giray Han (1554-1607) başarılı devlet adamlığı yanısıra edebiyat ve müzik ile ilgilenmiştir. Çeşitli müzik aletlerini çalabilen iyi bir sazende ve devrinin en güçlü bestekârlarından biri olan Gazi Giray'ın peşrev ve saz semailerinden altmış ikisi günümüze ulaşmıştır (Uzun, 1996: 452). Giray Han'ın Suzidilara makamında biri peşrev diğeri saz semaisi olmak üzere iki eseri divanmakam.com internet sitesinde E3001 arşiv numarasıyla yayınlanmaktadır. Gazi Giray'ın Suzidilara peşrevi ve Suzidilara saz semaisi makamsal olarak incelendiğinde günümüzde kullanılan Suzidilara makamı tarifinden daha çok Nigar ve Büzürk makamı tarifine daha uygun olduğu görülmektedir. Yakup Fikret Kutluğ’un Suzidilara makamı tarifine uygunluğu göze çarpmaktadır.

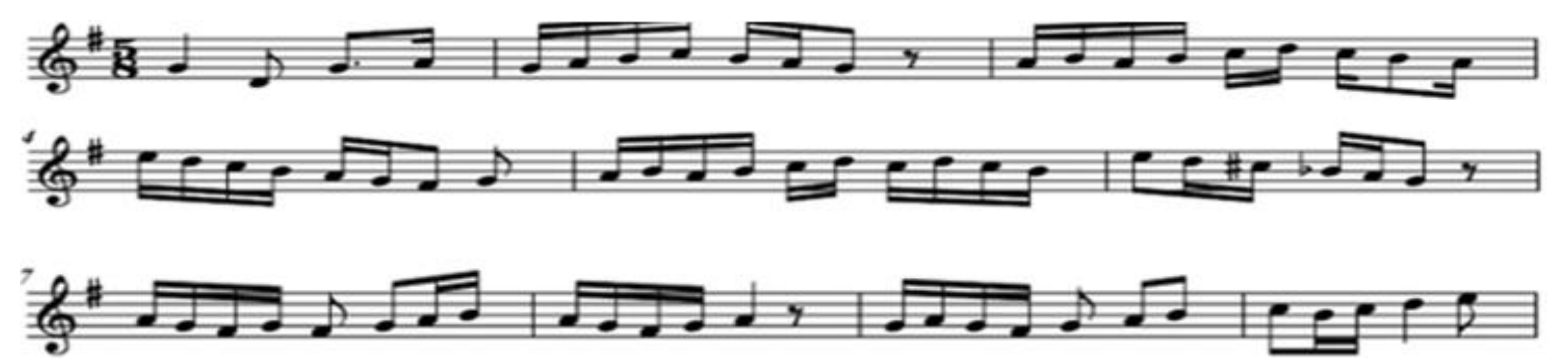

Şekil 10. "Suzidilara Saz Semaisi” Birinci Hane. (www.divan.com, 2019).

Birinci ve beşinci ölçü arası: Bu ölçüler incelendiğinde makamın durak sesi ve çevresinde seyre başlayan eserin Yegâh (re) perdesi üzerinde Rast dörtlüsü ve Rast (sol) perdesi üzerinde çıkıc1 Nigar beşlisinin kullanıldığı görülmektedir. Altıncı ölçü: Bu ölçü incelendiğinde Rast (sol) perdesi üzerinde inici Nikriz beşlisinin kullanıldığı görülmektedir. Yedinci ve onuncu ölçü arası: Bu ölçüler incelediğinde Dügâh (la) perdesi üzerinde inici Bûselik dörtlüsü ve Rast (sol) perdesi üzerinde Nigar beşlisinin seyir ettiği görülmektedir.

\subsubsection{Kantemiroğlu 'nun "Suzidilara Saz Semaisi” Adlı Eseri}

$\mathrm{Bu}$ eser 7286 numarasıly İstanbul Belediyesi Konservatuvarı kütüphanesinde bulunmaktadır. Cüneyt Koşal tarafından orijinal nüshasından kopya edilmiştir. Kantemiroğlu 'nun (1673-1723) Suzidilara peşrevi ve Suzidilara saz semaisi makamsal olarak incelendiğinde Gazi 
Giray'ın eserlerinde olduğu gibi Suzidilara makamı tarifinden daha çok Nigar ve Büzürk makamı dizilerinin kullanıldığı görülmektedir. Yakup Fikret Kutluğ’un Suzidilara makamı tarifine uygunluğu göze çarpmaktadır.

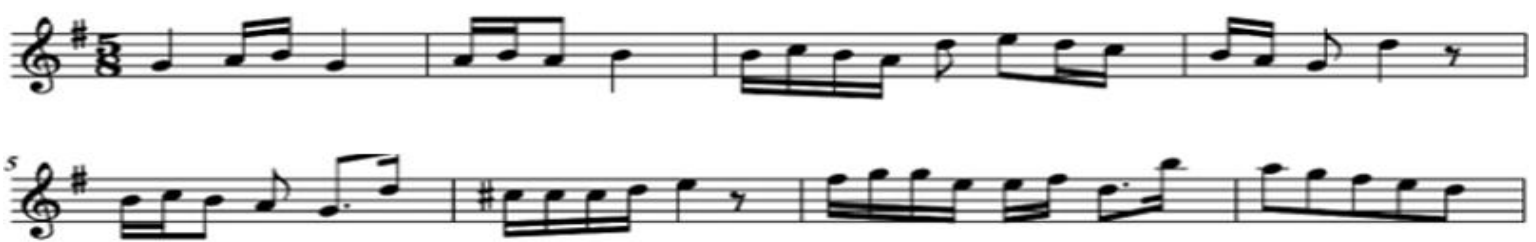

Şekil 11. "Suzidilara Saz Semaisi” Birinci Hane (www.divan.com, 2019).

Birinci ve beşinci ölçü arası: Bu ölçüler incelendiğinde seyrin dar bir alanda ezgilendiği ve Rast (sol) perdesi üzerinde çıkıcı Nigar beşlisinin kullanıldığı görülmektedir. Altıncı ölçü: $\mathrm{Bu}$ ölçüler incelendiğinde Neva (re) perdesi civarında Nişabur çeşnisi ve Neva (re) perdesi üzerinde Rast dörtlüsünün kullanıldığı görülmektedir. Yedinci ve sekizinci ölçü: Bu ölçüler incelendiğinde Neva (re) perdesi üzerinde Rast beşlisinin seyir ettiği görülmektedir.

\subsubsection{Raftâr Kalfa'nın "Suzidilara Saz Semaisi” Adlı Eseri}

Raftâr Kalfa (?) hayatı ile ilgili çok az bilgi olmasına rağmen müzik tarihi kaynaklarında adı geçmektedir. Suzidilara makamı terkibinden önce yaşadığı düşünülmektedir. $\mathrm{Bu}$ eser divanmakam.com internet sitesinde E3004 arşiv numarasıyla yayınlanmaktadır. "Suzidilara Peşrevi" ve "Suzidilara Saz Semaisi" eserlerinin tamamı incelendiğinde bestekâr eserlerinde Büzürk ve Buselik makamı dizilerini kullandığı görülmektedir.

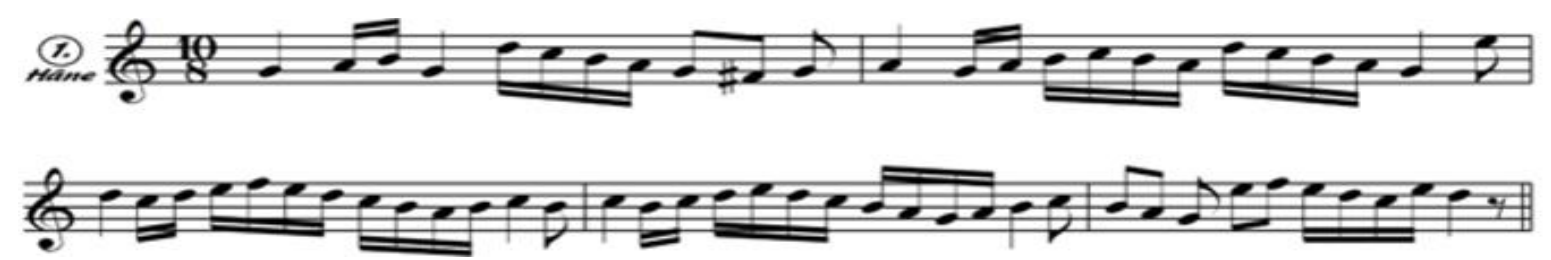

Şekil 12. "Suzidilara Saz Semaisi” Birinci Hane (www.divan.com, 2019).

Birinci ve üçüncü ölçü arası: Suzidilara makamın ana dizisini oluşturan, Rast (sol) perdesinde, Nigar makamı dizisini güçlü perdesi (re) üzerinde Bûselik dörtlüsünün kullanıldığ 1 görülmektedir. Rast (sol) perdesinde Nigar beşlisi ve Yegâh (re) perdesinde Rast dörtlüsünün gösterildiği, Yegâh (sol) perdesinde Rast'lı genişleme kullanıldığı görülmektedir.

\subsubsection{Ahmet Ăga'nın “Suzidilara Peşrevi” Adlı Eseri}

Ahmet Ağa (1728-1794) kendi döneminin önemli bestekârlarındandır. Ferahfeza makamını terkip etmiş ve Darb-1 Hüner adında 19 zamanlı usul bulmuştur. Ağırlık olarak Ayin-i Şerif ve saz eseri bestelemiştir (Şenoğlu, 1994: 2). "Suzidilara Peşrevi” eserinin tamamı incelendiğinde bestekâr eserinde Büzürk ve Buselik makamı dizilerini kullandığı görülmektedir. İstanbul Konservatuvarı Neşriyatından ilmi heyet tarafından tetkik ve kabul edilmiş olan bu eseri incelediğimizde makamın nazariyat açısından farklı bir dizisi ortaya çıkmaktadır. Bu eserde si (Bûselik) sesinde 1 komalık diyez işareti kullanılmıştır. Bu Arel-Ezgi-Uzdilek' in 24'lü ses sisteminin dışına çıkan bir durumdur. Bu eser için si (Bûselik) sesi natürel kabul edilmiştir. Makam dizisini oluşturan dörtlü-beşlilerin kurulumunu ve eserin içinde kullanılan çeşnilerin tespiti ona göre görülmüş ve yorumlanmaya çalışılmıştır. 


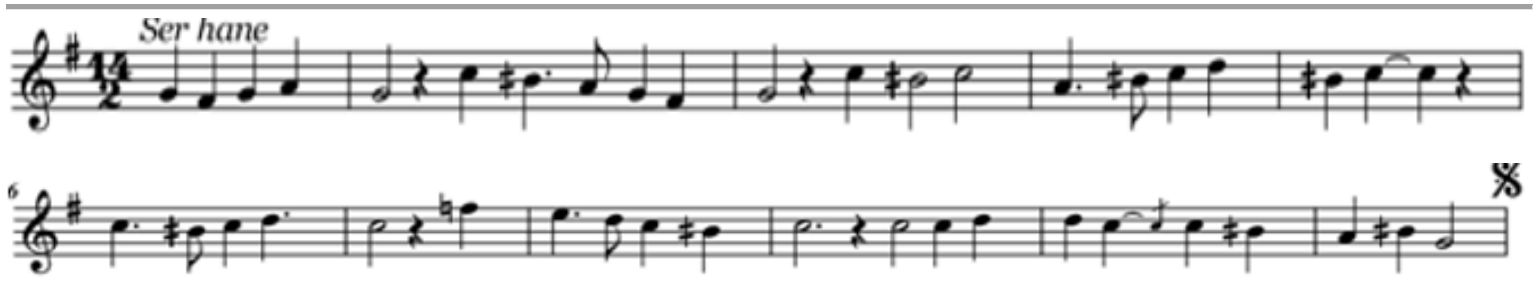

Şekil 13. "Suzidilara Peşrevi” Birinci Hane (www.notaarşivleri.com, 2019).

Birinci ölçü: $\mathrm{Bu}$ ölçüde Rast (sol) perdesi üzerinde Nigar dörtlüsünün kullanıldığı görülmektedir. İkinci ölçü: Çargâh (do) perdesinde Nigar dörtlüsü ve Rast (sol) perdesinde Nigar beşlisi kullanıldığını görmekteyiz. Sûz-i dîlârâ makamı ana dizisinin oluştuğu görülmektedir.

\subsubsection{Arapzâde'nin "Suzidilara Saz Semaisi”" Adı Eseri}

Suzidilara makamı terkibinden önce yaşamış olan Arapzâde'nin (?- 1746) "Suzidilara Peşrevi" ve "Suzidilara Saz Semaisi" eserlerinin tamamı incelendiğinde bestekâr eserlerinde Mahur ve Buselik makamı dizilerini kullandığı görülmektedir.

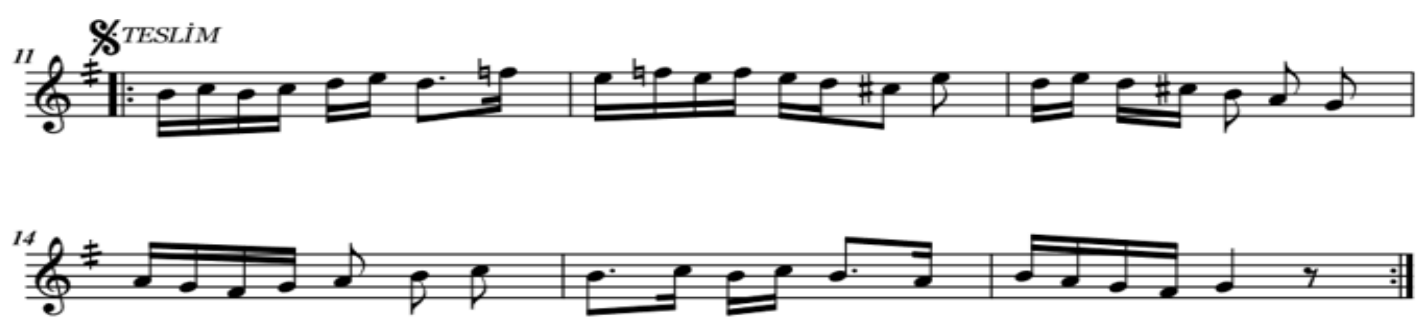

Şekil 14. "Suzidilara Saz Semaisi” Teslim Bölümü (www.divan.com, 2019).

Birinci ve dördüncü ölçü: $\mathrm{Bu}$ ölçüleri ele aldığımızda Nişabur dizisinin inici şekliyle kullanıldığı görülmektedir. Beşinci ve Altıncı ölçü: Bu ölçüleri ele aldığımızda Rast (sol) perdesinde Çargâh dörtlüsü ile Rast (sol) perdesinde Çargâh dörtlüsünün kullanıldığını ve Rast (sol) perdesinde karar verildiği görülmektedir.

\subsubsection{Sultan III. Selim'in “Suzidilara Ayini Şerif-i” Adlı Eseri}

Suzidilara makamının terkibini yapan III. Selim'in (1761-1808) bu makamda bestelediği eserler karşılaştırıldığında makamsal yapı olarak uyumsuzluk göze çarpmaktadır. Her iki Saz Semaisi'nin de kendi döneminden önce bestelenmiş olabileceği düşünülen eserlerle benzer makamsal yapıda oldukları görülmektedir. Diğer eserlerinde Mahur makamı dizisinin sık kullanıldığı görülmektedir. Bu durum göz önüne alındığından Selim'in eski bir makam olan Nigar ve Büzürk makamlarına Mahur makamı dizisini ekleyerek Suzidilara makamı dizisinin oluşturduğu düşünülebilir. Sultan III. Selim'in "Suzidilara Mevlevi Ayini Şerif-i” ve diğer eserlerinin tamamı incelendiğinde bestekâr eserlerinde Mahur, Büzürk ve Buselik makamı dizilerini kullandığı görülmektedir. 


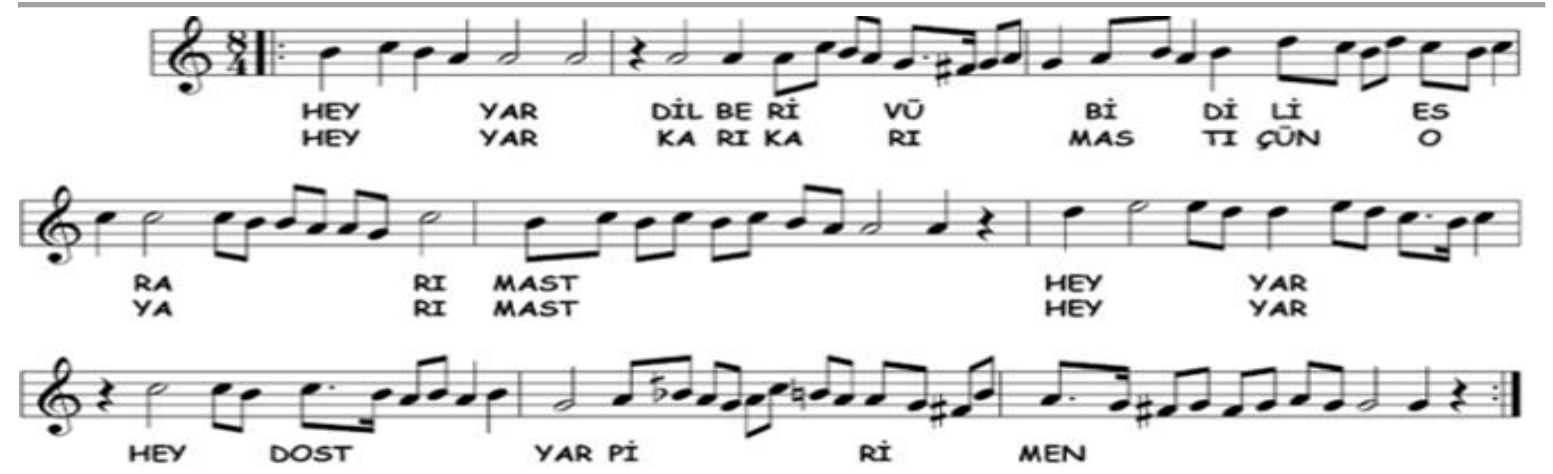

Şekil 15. "Suzidilara Ayini Şerif-i” Birinci Selam (www.neyzen.com, 2019).

Birinci ve yedinci ölçü arası: Eserin Birinci Selamında Dügâh (la) perdesinde Bûselik beşlisinin ilk sesiyle başlandığı görülmektedir. Abdulbaki Nasır Dedenin makamı tarif ettiği şekliyle başladığı görülmektedir. Ardından Rast (sol) perdesi üzerinde Büzürk makamı dizi özelliklerini kullanmaktadır. Çargâh (do) perdesi çevresinde gezinerek sonran Rast (sol), Dügâh, Çargâh ve Hüseyni perdelerinde kalışlar yaparak bu perdelere dikkat çekmektedir. Sekizinci ve dokuzuncu ölçü: $\mathrm{Bu}$ ölçüler incelendiğinde Rast (sol) perdesi üzerinde Nikriz beşlisinin ilk üç sesinin kullanıldığı ve ardından Rast (sol) perdesinde tam kalış yapıldığı görülmektedir.

\subsubsection{Kemani Rıza Efendi’nin "Seyret Oyuncu” Adlı Eseri}

Kemani Riza Efendi'nin (1780-1852) Suzidilara makamında bir eseri bulunmaktadır. Riza Efendi'nin eserinde daha yalın bir makamsal yapı göze çarpmaktadır. "Seyret Oyuncu" adlı eserinin tamamı incelendiğinde bestekâr eserinde Mahur ve Buselik makamı dizilerini kullandığ görülmektedir.

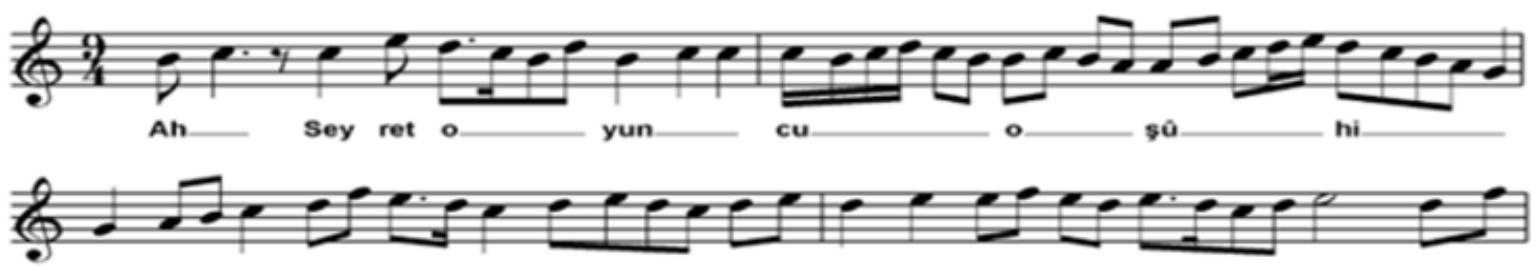

Şekil 16. "Seyret Oyuncu” Adlı Eser (www.neyzen.com, 2019).

Birinci ve ikinci ölçü: Bu ölçüler incelendiğinde Çargâh (do) perdesinde Çargâh beşlisinin ilk üç sesinin kullanıldığı görülmektedir. Üçüncü ve dördüncü ölçü: Bu ölçüler incelendiğinde Rast (sol) perdesi üzerinde Çargâh beşlisinin çıkıcı şeyliyle kullanıldığı ve Neva (re) perdesi Bûselik dörtlüsünün kullanıldığg görülmektedir. Beşinci ve altıncı ölçü: Bu ölçüler incelendiğinde Neva (re) perdesinde Bûselik dörtlüsünün kullanıldığı ve Rast (sol) perdesi üzerinde Çargâh beşlisinin kullanıldığı görülmektedir.

\subsubsection{Sultan II. Mahmut'un "Nihal-i Kametin" Adlı Eseri}

Sultan II. Mahmut'un (1785-1839) "Nihal-i Kametin" eserinde Suzidilara makamını III. Selim'in makamı kullanma biçimine yakın bir şekilde kullandığı görülmektedir. Büzürk dizisi ile başlamış ardından Mahur ve Nikriz makamı dizilerini karışık olarak işlemiştir. "Nihal-i Kametin" adlı eserin tamamı incelendiğinde bestekârın eserinde Büzürk ve Buselik makamı dizilerine ek olarak Nikriz makamı dizisi kullandığı görülmektedir. 


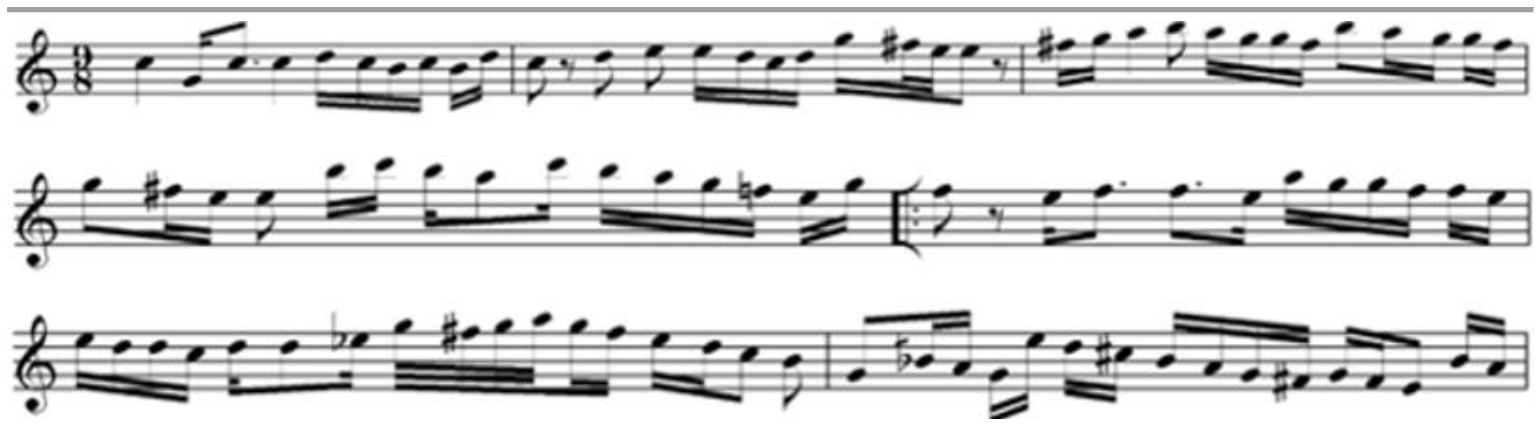

Şekil 17. "Nihal-i Kametin” Adlı Eser (www.neyzen.com, 2019).

Birinci ölçü: Çargâh (do) perdesi ve civarında Nigar'lı gezinerek başlandığı görülmektedir. Bestekârın eserleri incelendiğinde Sultan III. Selim ile aynı makam anlayışı paylaştığı görülmektedir. İkinci ve dördüncü ölçü arası: Neva (re) perdesi üzerinde Acemli Rast makamı dizisi çıkııı haliyle gösterildiği görülmektedir. Eserin bu kısmından itibaren makamı seyir özelliğinin gösterildiği görülmektedir. Beşinci ölçü: Bu ölçüde Hüseyni (mi) perdesi ve çevresinde Hüseyni'de Kûrdi çeşnisi ile gezindiği görülmektedir. Altıncı ölçü: Çargâh (do) perdesinde Nikriz beşlisinin çıkıcıinici halinin gösterildiği görülmektedir. Yedinci ölçü: Rast (sol) perdesinde Nikriz beşlisiyle kalış yapmadan çeşni olarak kullanıldığı ve bu aynı zamanda Rast' da Nikriz beşlisinin üstüne Neva'da Hicaz dörtlüsünün eklenmesiyle Neveser makamı dizisinin oluşturduğu görülmektedir.

\subsubsection{Dellalzâde'nin "Şehenșahın Cemalidir” Adı Eseri}

Dellalzâde'nin (1797-1869) Suzidilara makamında iki eseri bulunmaktadır. Bu eserlerin besteleri küçük farklılıklar dışında neredeyse aynıdır. Fakat güfteleri farklıdır. "Şehenşahın Cemalidir" ve "Keremkarın Cemalidir" adlı eserlerin tamamı incelendiğinde bestekâr eserlerinde Büzürk ve Buselik makamı dizilerini barındıran Nigar makamını kullandığı görülmektedir.

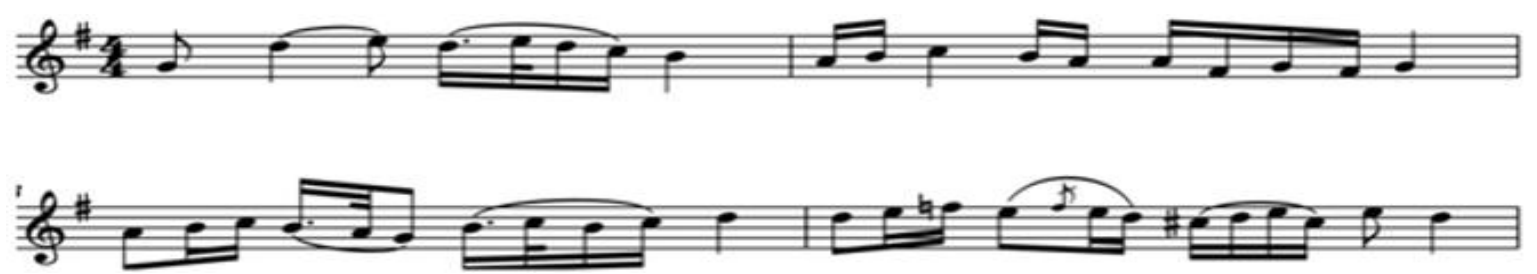

Şekil 18. "Şehenşahın Cemalidir" Adlı Eser (www.divan.com, 2019).

Birinci ve üçüncü ölçü arası: Rast (Sol) perdesinde Mahur dizisi kullanıldığı görülmektedir. Dördüncü ölçü: Neva $(\mathrm{Re})$ perdesinde Bûselik dörtlüsü kullanılarak Nim Hicaz (Do diyez) perdesi yeden olarak kullanıldığg görülmektedir.

\subsubsection{Nâyî Raşit Efendi’nin "Suzidilara Saz Semaisi”” Adlı Eseri}

Nâyî Raşit Efendi'nin (1820-1892), Suzidilara makamının terkibinden sonra bestelendiği açık olan, "Suzidilara Saz Semaisi" eserindeki makam kullanımının, III. Selim'in makamı ele alış şekliden uzak olduğu görülmektedir. Eserin tamamı incelendiğinde bestekâr eserinde Büzürk ve Buselik makamı dizilerini kullandığ 1 görülmektedir.

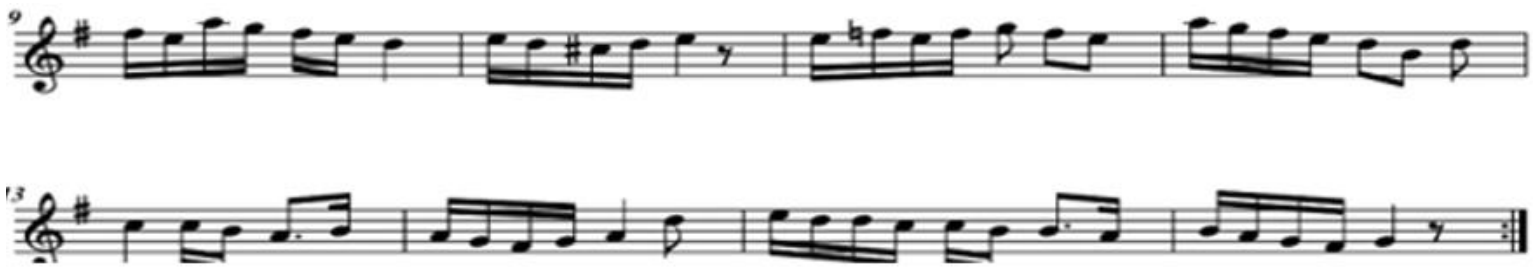

Şekil 19. "Suzidilara Saz Semaisi” Birinci Hane (www.divan.com, 2019). 
Birinci ve beşinci ölçü arası: $B u$ ölçüler incelendiğinde Bûselik (si) perdesi üzerinde Nişabur çeşnisi ve Neva (re) perdesi üzerinde Rast dörtlüsünün seyir ettiği görülmektedir. Altıncı ve sekizinci ölçü arası: Bu ölçüler incelendiğinde Rast (sol) perdesi üzerinde Nigar beşlisi, Dügâh (la) perdesi üzerinde Bûselik beşlisinin kullanıldığı ve Rast (sol) perdesinde karar verildiği görülmektedir.

\subsubsection{Zekai Dede'nin "Suzidilara Teşvih” Adlı Eseri}

Hamamizade İsmail Dede'den sonra en büyük bestecilerden biri olarak kabul edilen Zekâi Dede'nin (1825-1897) III. Selim'in Suzidilara makamını ele alış şekline uyduğu görülmektedir. Daha sade bir biçim kullandığı görülmektedir. "Suzidilara Teşvih" ve "Suzidilara Bârekallah" adlı eserlerinin tamamı incelendiğinde bestekâr eserlerinde Mahur, Büzürk ve Buselik makamı dizilerini kullandığ görülmektedir.

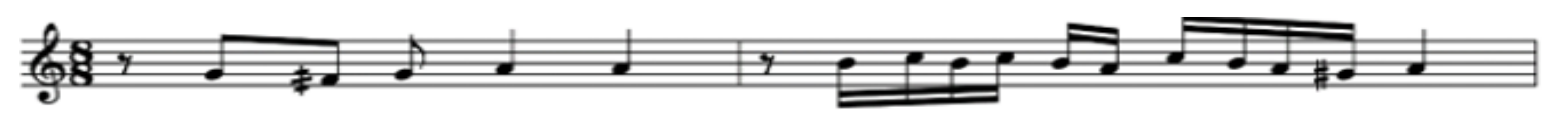

Şekil 20. “Suzidilara Teşvih” Bir Kısmı (www.divan.com, 2019).

Birinci ve ikinci ölçü: $\mathrm{Bu}$ Ölçüde Rast (sol) perdesinde çıkıcı Nigar dörtlüsünün ilk iki sesinin kullanıldığı görülmektedir. İkinci Ölçü, bu ölçüde Dügâh (la) perdesinde Bûselik beşlisinin ilk dört sesinin kullanıldığını ve Nim Zirgüle perdesi, bu ölçüde Dügâh (la) perdesinde gösterilen Bûselik Beşlisinin yedeni olarak kullanıldığı görülmektedir.

\subsubsection{Sultan Mehmet Vahdettin'in "Kıskanır Her Gece" Adlı Eseri}

Sultan Mehmet Vahdettin'in (1861-1926) Suzidilara makamında iki sözlü eseri bulunmaktadır. Eserlerin makamsal yapıları ele alındığında III. Selim'in makamsal anlayışının sürdürüldüğü görülmektedir. "Kıskanır Her Gece" ve "Öldürse de Aşkın Beni” adlı eserlerinin tamamı incelendiğinde bestekârın Mahur, Büzürk ve Buselik makamı dizilerini kullandığı görülmektedir.

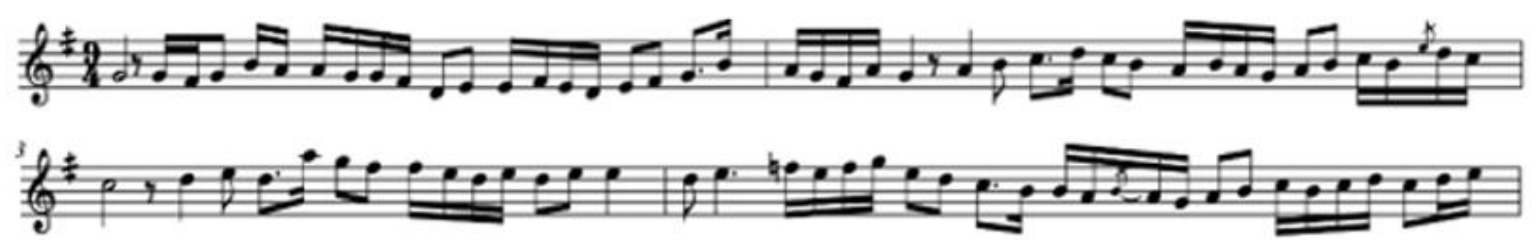

Şekil 21. "Kıskanır Her Gece" Adlı Eser (www.divan.com, 2019).

Birinci ve ikinci ölçü: Makamın karar sesi ve çevresinde gezindiği ve Yegâh (re) perdesi üzerinde Çargâh Makamı dizisi oluşturulduğu görülmektedir. Üçüncü ölçü: Çargâh (do) perdesi üzerinde makamın bir özelliği olan Çargâh beşlisi gösterildiği görülmektedir. Dördüncü ölçü: Bûselik makamı dizisi inici ve çıkıcı olarak gösterildiğini görülmektedir.

\subsubsection{Muallim İsmail Hakkı Bey'in "Bir Kesâfet Ârız Oldu” Adlı Eseri}

Muallim İsmail Hakkı Bey'in (1865-1927) Suzidilara makamını III. Selim'in makamı kullanma biçimine uygun olarak kullandığı görülmüştür. "Bir Kesâfet Ârız Oldu" ve "Va'd Etmiş İdin" adlı eserleri incelendiğinde bestekârın eserlerinde Mahur, Büzürk ve Buselik makamı dizilerini kullandığı görülmektedir. 

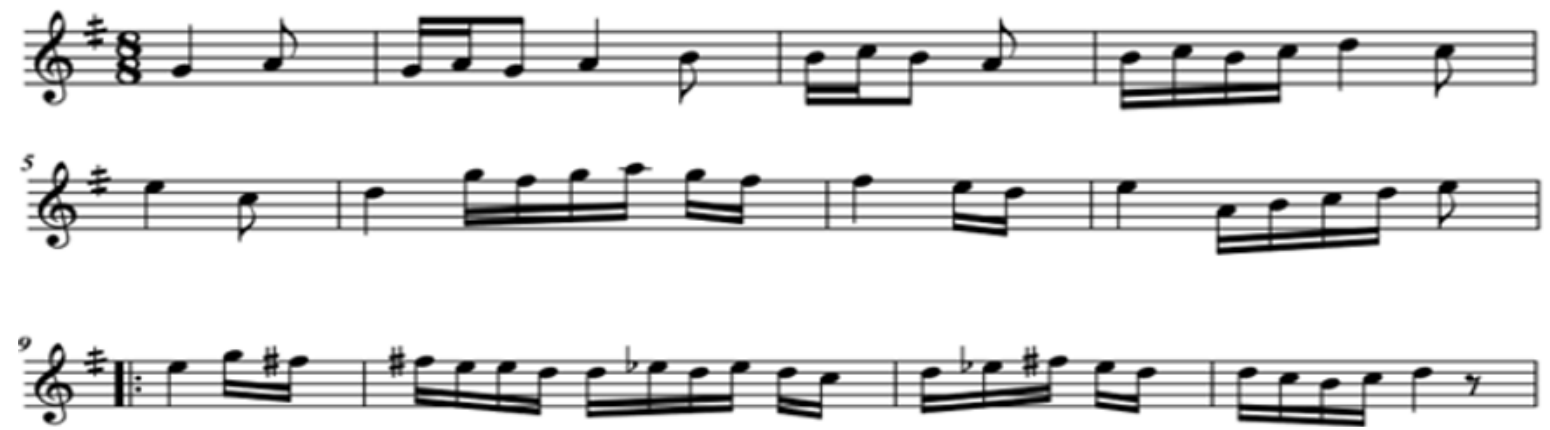

Şekil 22. "Bir Kesâfet Ârız Oldu” Adlı Eser (www.divan.com, 2019).

Birinci ve ikinci ölçü: $\mathrm{Bu}$ ölçüler incelendiğinde Rast (re) perdesinde Çargâh beşlisi kullanıldığı görülmektedir. Üçüncü ve dördüncü ölçü: Neva (re) perdesinde çıkıcı Çargâh ve inici Hüseyni (mi) perdesinde Bûselik kullanıldığını ardından çıkıcı Dügâh perdesinde Beşlisi kullanıldığını görülmektedir. Beşinci ve altıncı ölçü: Neva (re) perdesi üzerinde inici Hicaz dörtlüsü ve Çargâh (do) perdesinde inici Nikriz beşlisinin kullanıldığı görülmektedir.

\subsubsection{Tanburi Cemil Bey'in "Suzidilara Saz Semaisi” Adlı Eseri}

Cemil Bey (1871-1916) Suzidilara makamını Hüseyin Saadettin Arel'in tarifine uygun olarak kullanmıştır. Suzidilara makamını Mahur makamı dizisi üzerine kurmuş ve doğal olarak Buselik makamı oluşmuştur. "Suzidilara Saz Semaisi" eseri incelendiğinde bestekârın Mahur ve Buselik makamı dizilerini kullandığı görülmektedir.

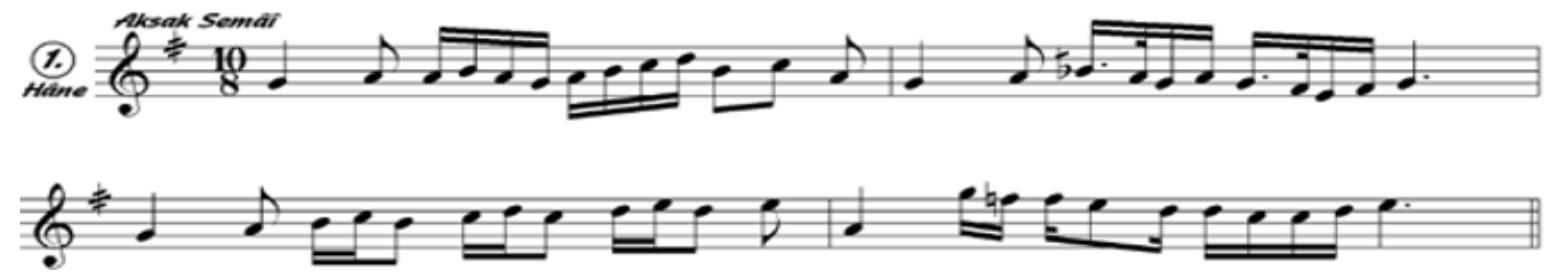

Şekil 23. “Suzidilara Saz Semaisi” Birinci Hane (www.neyzen.com, 2019).

Birinci ölçü: Rast perdesi ile Neva perdesi aralığında bir seyir izlediği, Rast perdesinde Çargâh beşlisinin kullanıldığı görülmektedir. İkinci ölçü: $\mathrm{Bu}$ ölçüyü incelediğimizde Hüseyni Aşiran perdesi ile Dik Kûrdi perdesi aralığında bir seyir izlediği ve ölçünün ilk beş sesinde Nikriz beşlisinin ilk üç sesinin kullanıldığını ardından Hüseyni Aşiran perdesinde Bûselik dörtlüsü kullanıldığını görmekteyiz. Üçüncü ve dördüncü ölçü: Bu ölçüleri ele aldığımızda Rast perdesi ile Hüseyni perdesi aralığında bir seyir izlediği ve Rast perdesi üzerinde Çargâh beşlisinin kullanıldığı görülmektedir. Neva perdesi üzerinde Bûselik dörtlüsü ve Çargâh perdesinde Çargâh dörtlüsünün ilk üç sesi kullanıldığını görülmektedir.

\subsubsection{5. Şehzâde Abdullah'ın “Geçti Sevdalarla Ömrüm” Adlı Eseri}

Şehzâde Abdullah (?) Suzidilara makamını, Büzürk makamı dizisini kullanarak III. Selim öncesi bestelendiği düşünülen Raftâr Kalfa, Bülbüloğlu ve III. Selim'in Suzidilara makamındaki iki Saz Semaisi ile aynı biçimi kullanmıştır. Şehzade Abdullah'ın "Geçti Sevdalarla Ömrüm” adlı eseri incelendiğinde bestekârın Büzürk ve Buselik makamı dizilerini kullandığg görülmektedir. 


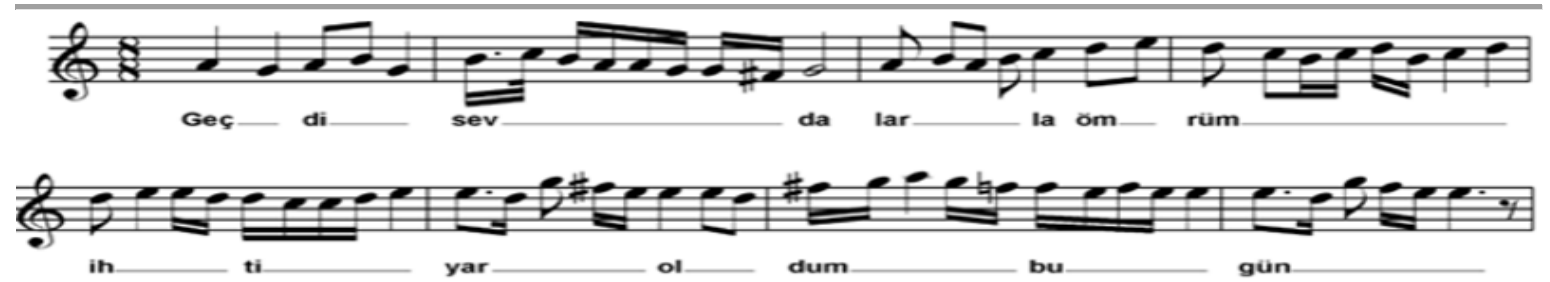

Şekil 24. "Geçti Sevdalarla Ömrüm” Adlı Eser (www.neyzen.com, 2019).

Birinci ve dördüncü ölçü arası: Rast (sol) perdesinde Nigar dörtlüsü inici-çıkıcı şekilde kullanıldığı görülmektedir. Bestekâr bu eserde Rast perdesindeki Nigar beşlisine ya da diziye yeden olarak Irak perdesi kullanıldığı görülmektedir. Beşinci ve sekizinci ölçü arası: Hüseyni (mi) perdesinde Uş̧̧ak dörtlüsünün kullanıldığı ve Acem (fa) perdesi altere ses olarak görülse de hüseyni perdesi Kûrdi 3 sesinin kullanıldığı görülmektedir.

\subsubsection{Udi Hasan Bey'in "Bu Hüsn ile Ey Gonca” Adlı Eseri}

Udi Hasan Bey (1868-1922) Suzidilara makamına Rast makamı çeşnisiyle başlamış ardından Buselik ve Mahur makamı dizisini kullanmıștır. Hasan Bey'in "Bu Hüsn ile Ey Gonca" adlı eserleri incelendiğinde bestekârın Mahur ve Buselik makamı dizilerini kullandığı görülmektedir.

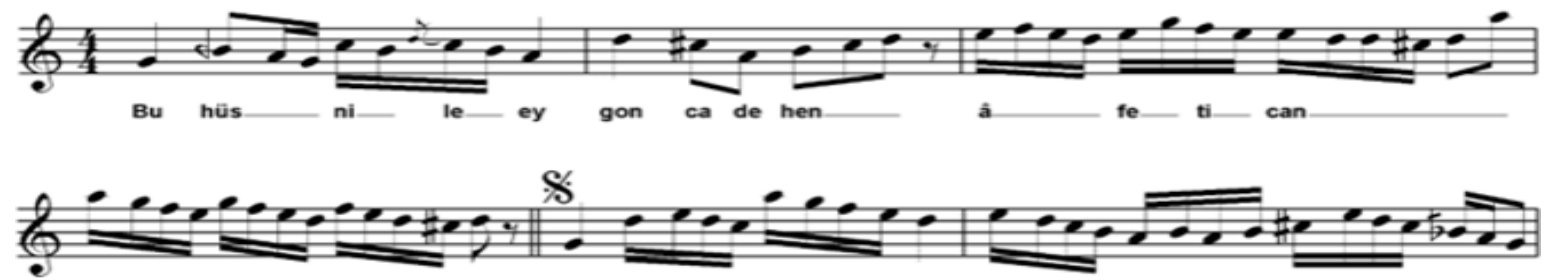

Şekil 25. "Bu Hüsn ile Ey Gonca" Adlı Eser (www.divan.com, 2019).

Birinci ölçü: Bu ölçü incelendiğinde Dügâh (la) perdesinde Uş̧̧ak dörtlüsü kullanıldığ görülmektedir. İkinci ve Üçüncü ölçü: Bu ölçüler incelendiğinde Dügâh (la) perdesinde Nişabur dörtlüsü ve Neva (re) perdesinde Bûselik beşlisi Nim Hicaz yeden ile gösterildiği görülmektedir. Dördüncü ölçü: $\mathrm{Bu}$ ölçü incelendiğinde Neva (re) perdesinde bûselik beşlisi gösterildiği görülmektedir. Beşinci ölçü: Bu ölçü incelendiğinde Makamın ana dizisi karışık gösterildiğini görülmektedir. Altıncı ölçü: Bu ölçü incelendiğinde Rast (sol) perdesinde Nikriz beşlisi gösterildiği görülmektedir.

\subsubsection{Hafiz Mehmet Efendi'nin “Sen Beni Terkeyliyelden” Adlı Eseri}

Hafız Mehmet Efendi'nin (?-1875) Suzidilara makamını III. Selim ile aynı anlayışta kullandığı görülmüştür. "Sen Beni Terkeyliyelden" adlı eseri incelendiğinde bestekârın Büzürk, Mahur ve Buselik makamı dizilerini kullandığı görülmektedir.

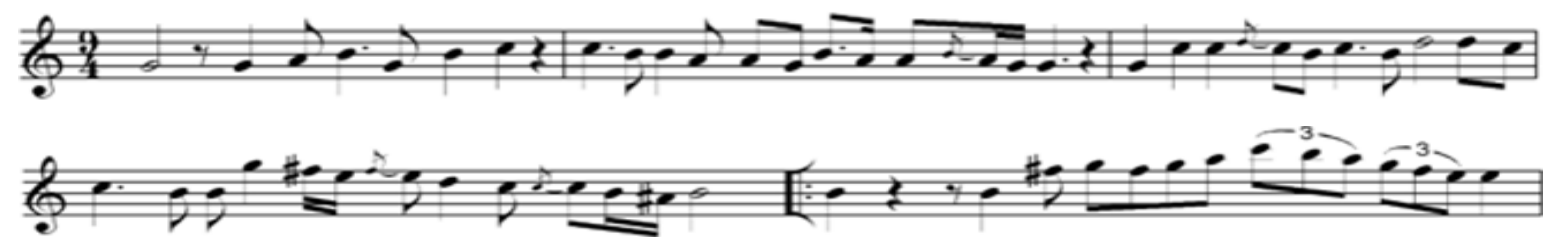

Şekil 26. "Sen Beni Terkeyliyelden” Adl1 Eser (www.divan.com, 2019).

Birinci ve üçüncü ölçü arası: Bu ölçüler incelendiğinde Rast (sol) perdesi üzerinde Çargâh beşlisinin kullanıldığı görülmektedir. Dördüncü ölçü: $\mathrm{Bu}$ ölçü incelendiğinde Bûselik (sol) perdesinde Kûrdi beşlisinin kullanıldığı ve Kûrdi (la diyez) perdesinde yeden olarak görülmektedir. Beşinci ölçü: $\mathrm{Bu}$ ölçüde Hüseyni (mi) perdesi üzerinde Hüseyni beşlisinin kullanıldığı görülmektedir. 


\subsubsection{Manok Ăga'nın "Ey Nev-bahâr-ı Ü Naz" Adlı Eseri}

Manok Ağa'nın (?-1902) Suzidilara makamında Büzürk ve Buselik dizilerini ağırlıklı olarak kullandığı ve yeden olarak Geveşt perdesini kullandığı görülmektedir. "Ey Nev-bahâr-1 ü Naz" adlı eseri incelendiğinde bestekârın Büzürk ve Buselik makamı dizilerini kullandığı görülmektedir.

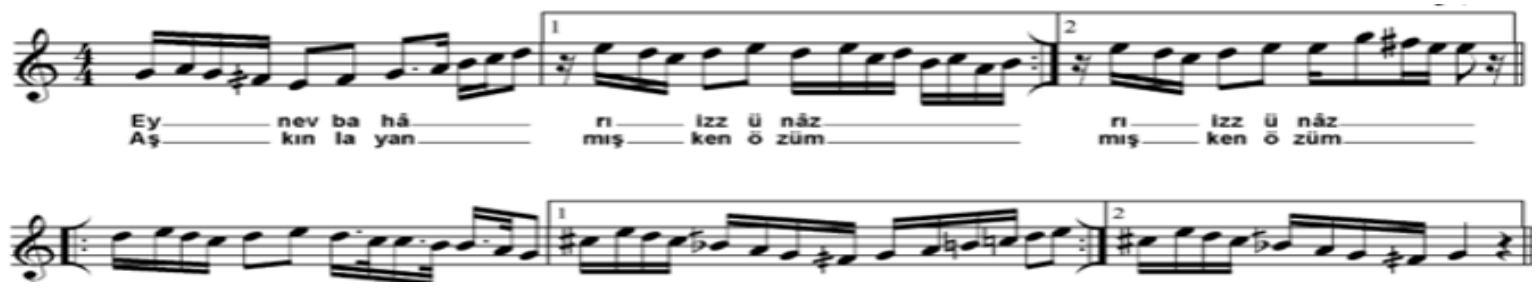

Şekil 27. "Ey Nev-bahâr-1 ü Naz" Adl1 Eser (www.divan.com, 2019).

Birinci ölçü: Rast (sol) perdesinde Nigar beşlisinin çıkıcı haliyle kullanıldığı görülmektedir. İkinci ölçü: $\mathrm{Bu}$ ölçüde Dügâh (la) perdesinde Bûselik beşlisinin inici haliyle kullanıldığı görülmektedir. Üçüncü ölçü: Bu ölçü incelendiğinde Hüseyni (mi) perdesinde Uşşak çeşnişi gösterildiği görülmektedir. Dördüncü ölçü: Hüseyni (mi) perdesinden başlayarak Rast (sol) perdesindeki Nigar beşlisi inici olarak kullanıldığı görülmektedir. Beşinci ve altıncı ölçü: Rast (sol) perdesindeki Nikriz beşlisi inici olarak kullanılarak Rast (sol) perdesinde yarım kalış yapıldığı görülmektedir.

\subsubsection{Alâeddin Yavaşça'nın "Hasretin Meltem Gibi” Adlı Eseri}

Alâeddin Yavaşça'nın (1951-2018) Suzidilara makamını Büzürk, Buselik ve Hüseyni Aşiran perdesinde Buselik dizisini işleyerek III. Selim'in makamı kullanma biçimine yakın kullandığı görülmüştür. "Hasretin Meltem Gibi" adlı eseri incelendiğinde bestekârın Büzürk ve Buselik makamı dizilerini kullandığı görülmektedir.

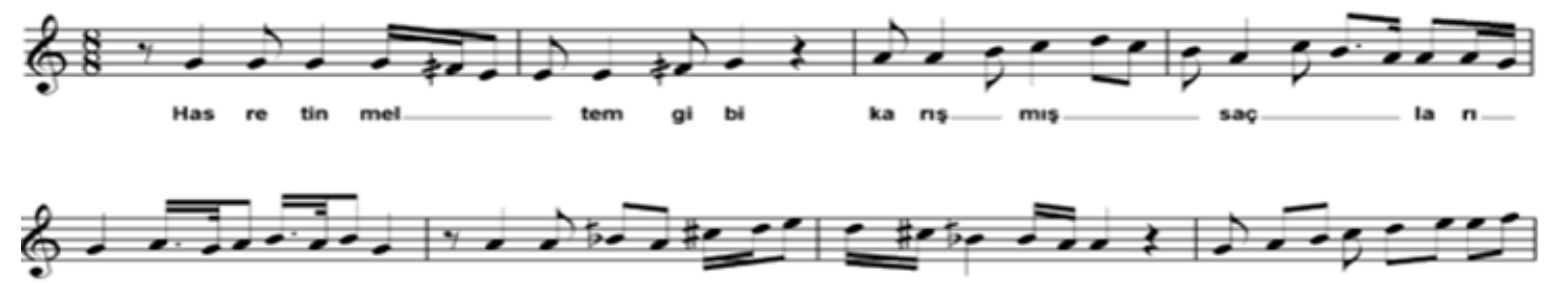

Şekil 28. "Hasretin Meltem Gibi” Adlı Eser (www.divan.com, 2019).

Birinci ve ikinci ölçü: Hüseyni Aşiran (mi) perdesinde Bûselik dörtlüsünün ilk üç sesinin kullanıldığı görülmektedir. Üçüncü ve beşinci ölçü arası: Makamın dizisini oluşturan Rast (sol) perdesindeki Çargâh beşlisinin gösterildiği ve Rast perdesinde kalış yapıldığı görülmektedir. Altıncı ve yedinci ölçü: $\mathrm{Bu}$ ölçülerde Dügâh (la) perdesinde Hicaz dörtlüsü çıkıcı ve inici şekliyle gösterildiği görülmektedir. Sekizinci ölçü: Makamın ana dizisini oluşturan Rast (sol) perdesinde Çargâh dörtlüsü ve Çargâh (do) perdesinde Çargâh beşlisiyle gezindiği görülmektedir.

\subsubsection{Necdet Varol'un "Suzidilara Peşrevi” Adlı Eseri}

Necdet Varol (1925- -) Suzidilara makamını makamsal olarak zengin bir seyirle kullanmıştır. "Suzidilara Peşrev" eseri incelendiğinde bestekârın Mahur, Rast ve Buselik makamı dizilerini kullandığı görülmektedir. 


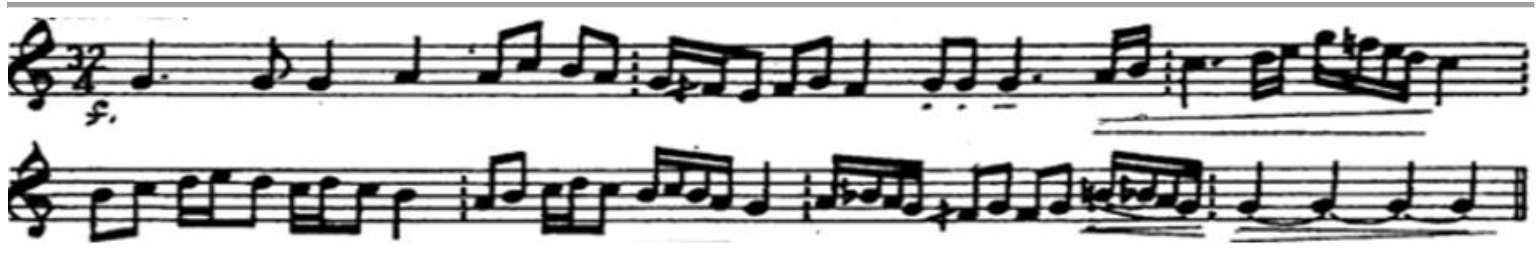

Şekil 29. "Suzidilara Peşrevi” Birinci Hane (www.divan.com, 2019).

Birinci ölçü: Bu ölçü incelendiğinde Rast (sol) perdesinde Çargâh dörtlüsünün kullanıldığ1 görülmektedir. Hüseyni Aşiran (mi) perdesinde Bûselik dörtlüsünün kullanıldığ 1 görülmektedir. Çargâh (do) perdesinde Çargâh dörtlüsünün kullanıldığı, Bûselik (si) perdesinde Kûrdi dörtlüsünün kullanıldığı görülmektedir. Rast (sol) perdesinde Çargâh beşlisinin kullanıldığı ve Rast (sol) perdesinde Nikriz beşlisinin ilk üç sesinin kullanıldığ 1 ve Rast (sol) perdesinde tam kalış yapıldığ görülmektedir.

\subsubsection{Akın Özkan'nın “Ben Kalemsem Sende Canan” Adlı Eseri}

Akın Özkan (1934-2007) Suzidilara makamında iki eser bestelemiştir. Hüseyin Saadettin Arel'in makamı tarif ettiği gibi kullanmıştır. Akın'ın "Suzidilara Peşrevi” ve "Ben Kalemsem Sende Canan" adlı eserleri incelendiğinde bestekârın Mahur ve Buselik makamı dizilerini kullandığı görülmektedir.

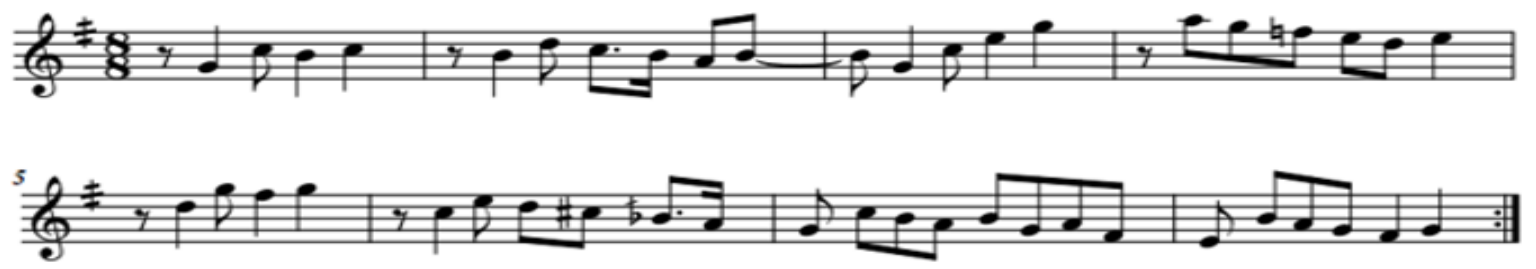

Şekil 30. "Ben Kalemsem Sende Canan” Adlı Eser (www.divan.com, 2019).

Birinci ve üçüncü ölçü arası: Suzidilara makamı ana dizisinin kullanıldığı görülmektedir. Dördüncü ölçü: Hüseyni perdesinde Kûrdi dörtlüsü ile yarım kalış kullanıldığ görülmektedir. Beşinci ölçü: Bu ölçüde Neva perdesinde Çargâh dörtlüsü kullanıldığı görülmektedir. Altıncı ölçü: Rast perdesine Nikriz'li inildiği görülmektedir. Yedinci ve sekizinci ölçü: $\mathrm{Bu}$ ölçüyü incelediğimizde Rast perdesinde Çargâh dörtlüsünün kullanıldığı ve Hüseyni Aşiran perdesinde Nişabur üçlüsünün kullanıldığ 1 görülmektedir.

\subsubsection{Cinuçen Tanrıkorur'un "Suzidilara Semai" Adlı Eseri}

Cinuçen Tanrıkorur'un (1938-2000) Suzidilara makamını Rauf Yekta Bey ve Gülçin Yahya Kaçar'ın makamı tarif ettiği şekliyle kullandığı görülmektedir. Tanrıkorur'un "Suzidilara Semai" adlı eserinin tamamı incelendiğinde bestekârın Rast ve Hüseyni makamı dizilerini kullandığ görülmektedir.

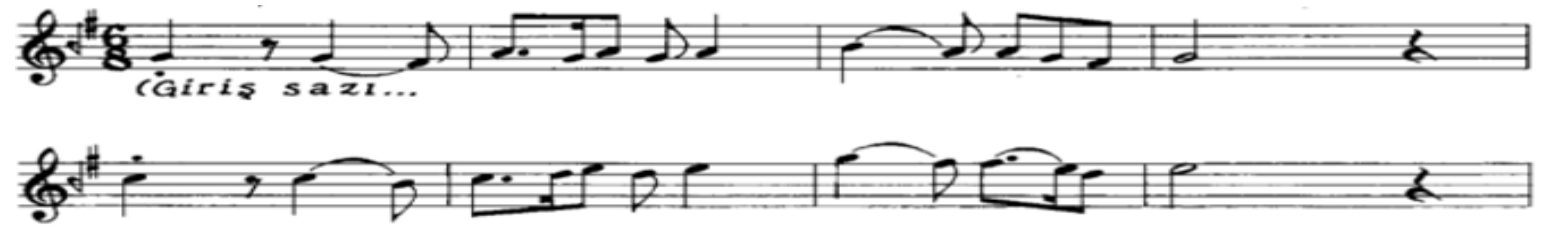

Şekil 31. "Suzidilara Semai” Bir Kısmı (www.divan.com, 2019).

Birinci ve dördüncü ölçü arası: Bestekâr Suzidilara makamını farklı bir anlayış ile yorumladığını eserin donanım kısmına baktığımızda anlayabiliriz. Rast (sol) perdesi ve çevresinde Rast'lı gezindiği görülmektedir Beşinci ve sekizinci ölçü arası: $\mathrm{Bu}$ ölçülerde Çargâh (do) 
perdesinde Çargâh'lı gezindiği ve Hüseyni (mi) perdesinde Uşşak'lı yarım kalış yapıldığ1 görülmektedir.

\subsubsection{Fethi Karamahmudoğlu'nun "Şehir Durgun" Adlı Eseri}

Fethi Karamahmudoğlu'nun (1942-1999) Suzidilara makamını III. Selim ile aynı anlayıșta kullandığı görülmüştür. Karamahmudoğlu'nun "Şehir Durgun" adlı eserinin tamamı incelendiğinde bestekârın Mahur, Büzürk ve Buselik makam dizilerini kullandığı görülmektedir.

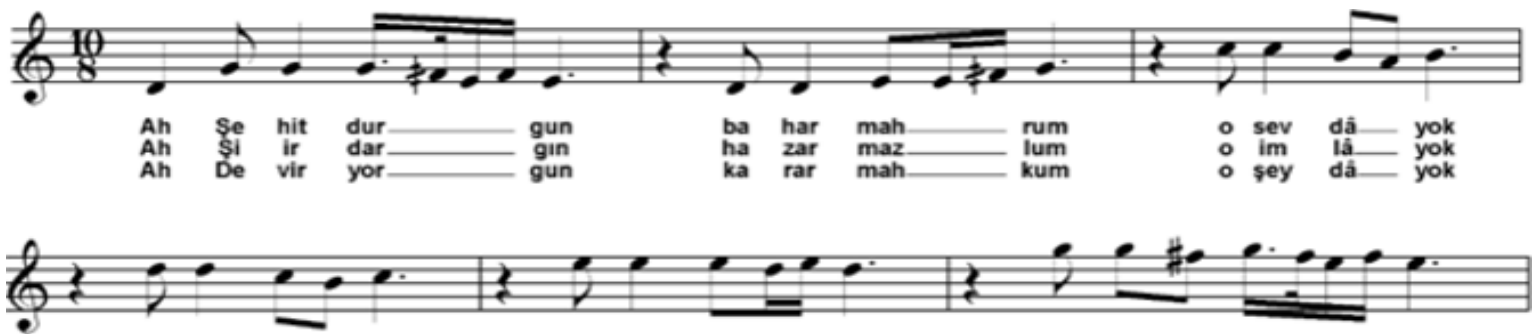

Şekil 32. "Şehir Durgun” Adlı Eser (www.neyzen.com, 2019).

Birinci ve üçüncü ölçü arası: Yegâh (re) perdesinde Çargâh dörtlüsü gösterilmiş ve Bûselik (si) perdesinde yarım kalış yapıldığını görülmektedir. Dördüncü ölçü: Bu ölçüyü incelediğimizde Çargâh (do) perdesinde Çargâh beşlisinin kullanıldığı görülmektedir. Beşinci ölçü: Bu ölçüyü ele aldığımızda Neva (re) perdesinde Bûselik dörtlüsünün kullanıldığı görülmektedir. Altıncı ölçü: Hüseyni (mi) perdesinde Uşşak dörtlüsü çeşni olarak gösterildiği ve yarım kalış yapıldığı görülmektedir.

\subsubsection{Sadeddin Çevik'in "Kim Görse Bakıp Halime" Adlı Eseri}

Sadeddin Çevik (?) Suzidilara makamını ele alırken Mahur ve Çargâh makamı dizilerini kullanmıştır. Çevik'in "Kim Görse Bakıp Halime" adlı eserinin tamamı incelendiğinde bestekârın Mahur ve Çargâh makamı dizilerini kullandığı görülmektedir.

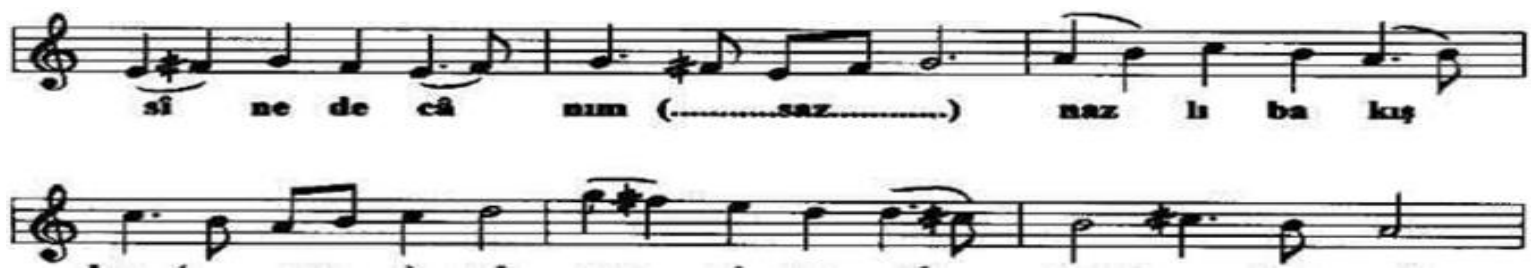

Şekil 33. "Kim Görse Bakıp Halime” Adlı Eser (www.divan.com, 2019).

Onuncu ve on birinci ölçü: Bu ölçülerde Hüseyni Aşiran (mi) perdesinde Bûselik üçlüsünün kullanıldığı görülmektedir. On ikinci ve on üçüncü ölçü: Bu ölçülerde Dügâh (la) perdesi üzerinde Bûselik dörtlüsünün kullanıldığı görülmektedir. On dördüncü ve on beşinci ölçü: $\mathrm{Bu}$ ölçüler incelendiğinde Neva (re) perdesi üzerinde Çargâh dörtlüsü ve Dügâh (la) perdesi üzerinde Çargâh dörtlüsünün kullanıldığı görülmektedir.

\subsubsection{H. Hüsnü Üstün'ün "Suzidilara Medhal” Adlı Eseri}

Hüsnü Üstün (1956--) Suzidilara makamını Mahur ve Nikriz makamı dizilerini kullanarak işlemiştir. Üstün'ün "Suzidilara Medhal” ve "Düş̧üm Olunmaz" Derde adlı eserlerinin tamamı incelendiğinde bestekârın Mahur ve Çargâh makamı dizilerini kullandığı görülmektedir. 


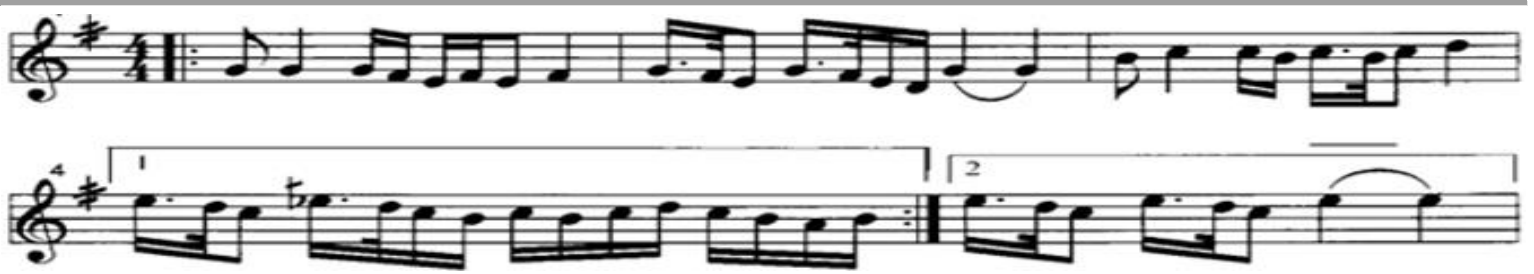

Şekil 34. "Suzidilara Medhal" Birinci Hane (www.divan.com, 2019).

Birinci ölçü: Hüseyni Aşiran (mi) perdesi üzerinde Bûselik dörtlüsünün ilk üç sesinin kullanıldığı görülmektedir. İkinci ölçü: Yegâh (re) perdesinde Çargâh dörtlüsü kullanıldığı görülmektedir. Üçüncü ölçü: Bu ölçüde Bûselik (si) perdesinde çıkıcı Kûrdi dörtlüsünün ilk üç sesinin kullanıldığı görülmektedir. Dördüncü ölçü: $\mathrm{Bu}$ ölçü incelendiğinde Dügâh (la) perdesi üzerinde Bûselik beşlisinin kullanıldığını ve Dik Hisar perdesinin altere olarak kullanıldığı görülmektedir. Beşinci ölçü: Çargâh (do) perdesi üzerinde inici Çargâh dörtlüsü ve Hüseyni (mi) perdesinde kalış yapıldığı ve teslime dönüldüğg̈ görülmektedir.

\subsubsection{Bülbüloğlu’nun “Suzidilara Saz Semaisi” Adlı Eseri}

Bülbüloğlu'nun (?) yaşadığı dönem ile ilgili hiçbir bilgi bulunmamaktadır. Bestekâr muhtemelen III. Selim'den daha önce yaşamıştır. Bülbüloğlu'nun "Suzidilara Peşrevi" ve "Suzidilara Saz Semaisi" eserlerinin tamamı incelendiğinde bestekârın Büzürk ve Buselik makam dizilerini kullandığı görülmektedir.

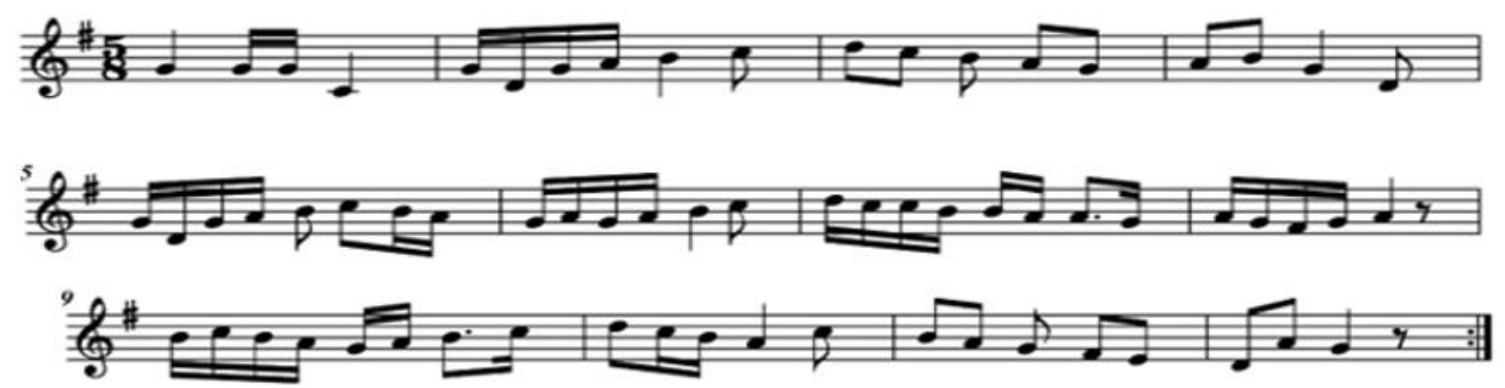

Şekil 35. "Suzidilara Saz Semaisi” Birinci Hane (www.divan.com, 2019).

Birinci ve üçüncü ölçü arası: Bu ölçüleri incelediğimizde Rast (sol) perdesi üzerinde çıkıcı Çargâh beşlisinin kullanıldığı görülmektedir. Dördüncü ve altıncı ölçü arası: $B u$ ölçüleri incelediğimizde Yegâh (re) perdesi üzerinde çıkıc1 Rast dörtlüsünün kullanıldığı görülmektedir. Yedinci ve onuncu ölçü arası: Bu ölçüleri incelediğimizde Dügâh (la) perdesi üzerinde inici Bûselik dörtlüsünün seyir ettiği görülmektedir. On birinci ölçü: Bu ölçüyü incelediğimizde Hüseyni Aşiran (mi) perdesi üzerinde inici Uşşak dörtlüsünün kullanıldığı görülmektedir. On ikinci ölçü: Bu ölçüyü incelediğimizde Yegâh (re) perdesi üzerinde çıkıc1 Rast dörtlüsünün kullanıldığı görülmektedir.

\subsubsection{Selim Dede'nin "Suzidilara Saz Semaisi”" Adlı Eseri}

Çoğu kaynakta III. Selim ile Selim Dede karıştırılmaktadır. Selim Dede 18 yüzyılda Galata Dergâhı matbahımda görevlidir. Muallim İsmail Hakkı Bey'in nota koleksiyonunda bu eserin Selim Dede'ye ait olduğunu açıkça anlamaktayız (Koç, 2003: 178). Dede'nin "Saz Semaisi” eserinin tamamı incelendiğinde bestekârın Büzürk ve Buselik makam dizilerini kullandığı görülmektedir.

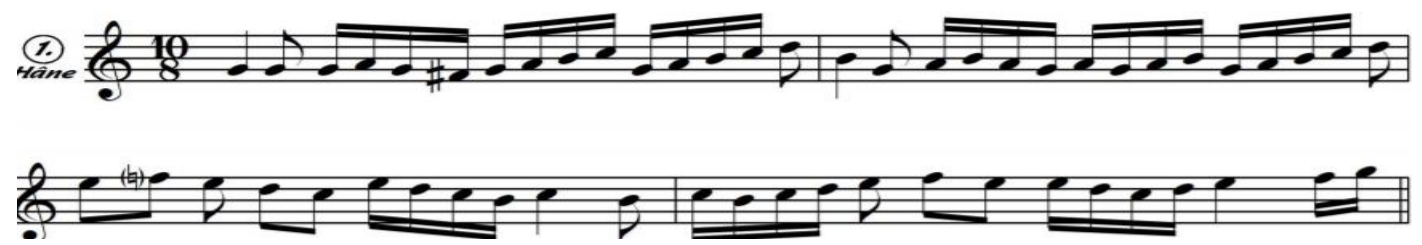

Şekil 36. “Suzidilara Saz Semaisi” Birinci Hane (www.neyzen.com, 2019). 
Birinci ölçü: $\mathrm{Bu}$ ölçü incelendiğinde Hüseyni (mi) perdesinde Kûrdi dörtlüsünün kullanıldığg görülmektedir. İkinci ölçü: Bu ölçü incelendiğinde Rast (sol) perdesinde Çargâh beşlisinin kullanıldığı görülmektedir. Üçüncü ölçü: Bu ölçü incelendiğinde Yegâh (re) perdesinde Çargâh dörtlüsünün kullanıldığı görülmektedir. Dördüncü ölçü: Bu ölçü incelendiğinde Hüseyni Aşiran (mi) perdesinde Bûselik üçlüsünün kullanıldığı görülmektedir.

\subsubsection{Sıtkı Sahil'in “Gönlüm Uyansın” Adlı Eseri}

Sitkı Sahil (1955- -) Suzidilara makamını Mahur ve Nikrizi dizilerini kullanarak işlemiştir. Sahil'in "Gönlüm Uyansın" adlı eserinin tamamı incelendiğinde bestekârın Mahur makamı dizisini kullandiğı görülmektedir.

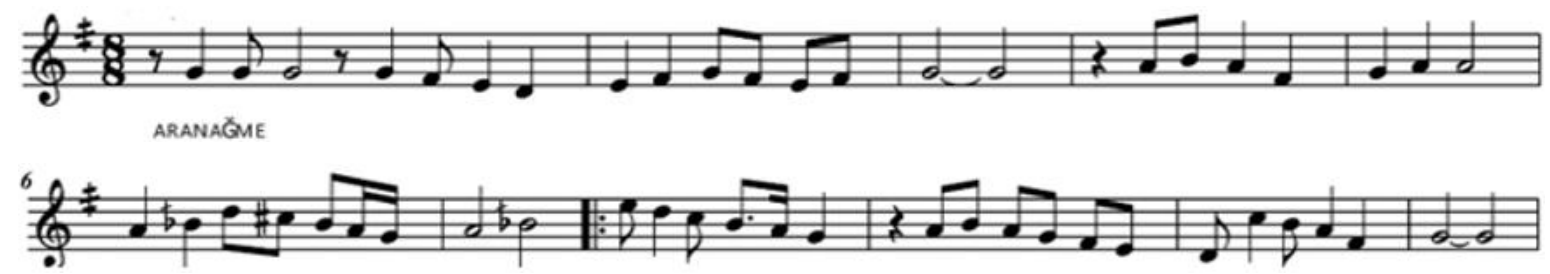

Şekil 37. “Gönlüm Uyansın” Adlı Eser (www.divan.com, 2019).

Birinci ve ikinci ölçü: Bu ölçüler beraber incelendiğinde Yegâh (re) perdesinde Çargâh dörtlüsünün kullanıldığını görülmektedir. Üçüncü ve dördüncü ölçü: $\mathrm{Bu}$ ölçüler birlikte ele alındığında Hüseyni Aşiran (mi) perdesinde Bûselik çeşnisinin kullanıldığı görülmektedir. Beşinci ve altıncı ölçü: $\mathrm{Bu}$ ölçüler ele alındığında Geveşt (fa 5 koma diyez ) perdesinde Kûrdi dörtlüsünün kullanıldığı görülmektedir. Yedinci ve sekizinci ölçü: $\mathrm{Bu}$ ölçüler ele alındığında Rast (sol) perdesinde Nikriz beşlisinin kullanıldığ 1 görülmektedir. Dokuzuncu ve on ikinci ölçü arası: $\mathrm{Bu}$ ölçüler incelendiğinde Rast (sol) perdesinde Çargâh beşlisi, Hüseyni Aşiran (mi) perdesinde Bûselik dörtlüsünün ilk üç sesinin kullanıldığı, Yegâh (re) perdesinde Çargâh dörtlüsü kullanıldığ 1 ve Rast (sol) perdesinde tam kalış yapıldığı görülmektedir.

\subsubsection{Varujan Zilciyan'ın "Suzidilara Peşrevi” Adlı Eseri}

Varujan Zilciyan (?-2018) 26 makam terkip etmiş olan bestekârdır ve Suzidilara makamında bestelediği eserini III. Selim'e ithaf etmiştir. Makamı Mahur dizisiyle almış ve kullanmıştır. Zilciyan'ın "Suzidilara Peşrevi” eserinin tamamı incelendiğinde bestekârın Mahur ve Çargâh makamı dizilerini kullandığı görülmektedir.

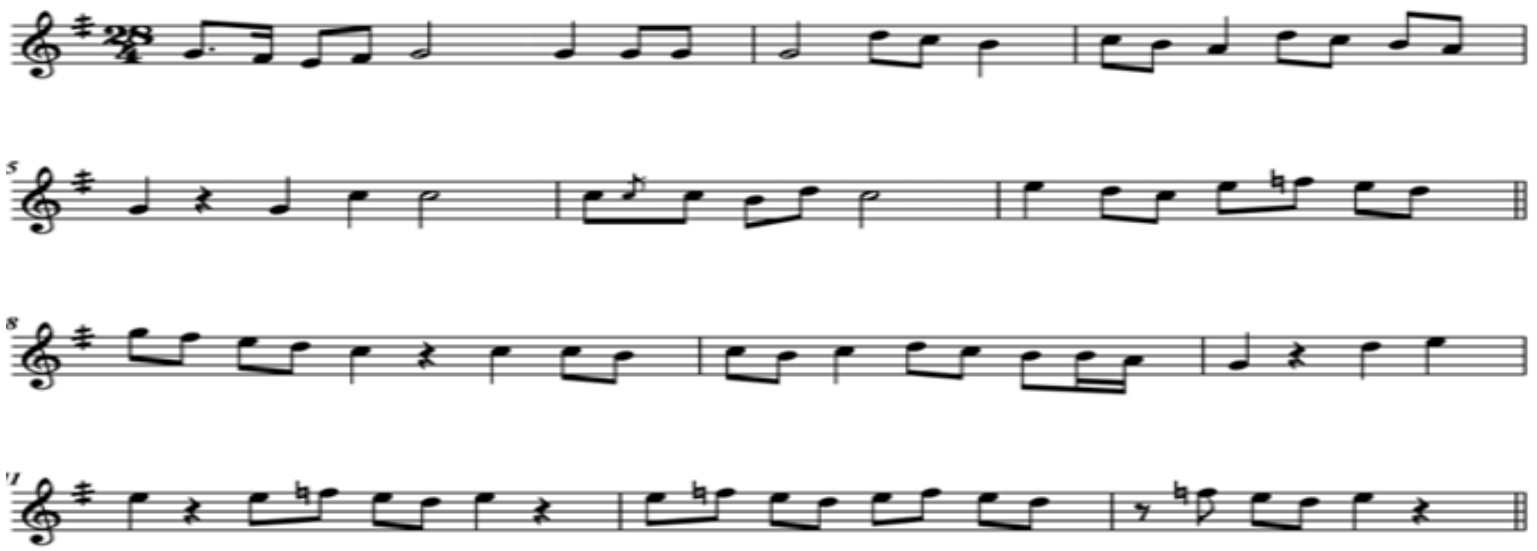

Şekil 38. "Suzidilara Peşrevi” Birinci Hane (www.divan.com, 2019).

Birinci ve üçüncü ölçü arası: Hüseyni (mi) Aşiran perdesin Nişabur üçlüsünün kullanıldığı Rast (sol) perdesinde Çargâh beşlisinin kullanıldığı görülmektedir. Dördüncü ve beşinci ölçü: Çargâh (do) perdesi çevresinde Çargâh'lı seyrettiği ve Çargâh perdesinde yarım kalış yapıldığı 
görülmektedir. Altıncı ve yedinci ölçü: Neva (re) perdesinde Bûselik dörtlüsü ve Çargâh (do) perdesinde Çargâh beşlisinin kullanıldığı görülmektedir. Sekizinci ve on ikinci ölçü arası: Dügâh (la) perdesinde Bûselik beşlisinin kullanıldığı ve ardından Hüseyni (mi) perdesinde Kürdili yarım kalış yapıldığı görülmektedir.

\subsubsection{Yalçın Mıhçı’nın "Ne Müşkildir Candan” Adıı Eseri}

Yalçın Mıhçı (?) Suzidilara makamını Mahur dizisini kullanarak işlemiştir. Mıhçı'nın "Ne Müşkildir Candan" adlı eseri incelendiğinde bestekârın Mahur ve Çargâh makamı dizilerini kullandığı görülmektedir.

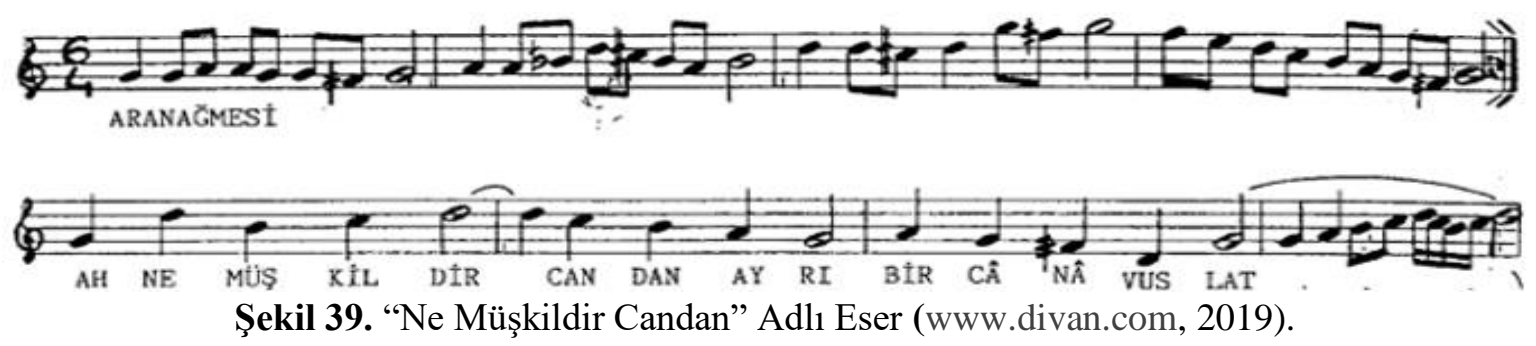

Birinci ölçü: Rast (sol) perdesinde Çargâh'lı gezinip kalış yapıldığı görülmektedir. İkinci ve üçüncü ölçü: $\mathrm{Bu}$ ölçüleri ele aldığımızda Dügâh (la) perdesinde çıkıcı Hicaz dörtlüsü ve Neva (re) perdesi üzerinde çıkıcı Çargâh dörtlüsünün kullanıldığını görülmektedir. Dördüncü ölçü: $\mathrm{Bu}$ ölçüde Rast (sol) perdesi üzerinde Çargâh dizisi kullanıldığı görülmektedir. Beşinci ve altıncı ölçü: Rast (sol) perdesinde çıkıcı-inici Çargâh dörtlüsünün kullanıldı̆̆ı görülmektedir. Yedinci ve sekizinci ölçü: $\mathrm{Bu}$ ölçülerde Yegâh (re) perdesinde inici Çargâh dörtlüsünün kullanıldığı ardından Rast (sol) perdesi üzerinde çıkıcı Çargâh beşlisinin kullanıldığı görülmektedir.

\subsubsection{Erol Sayan'ın "Uydum Kaderin Hükmüne” Adlı Eseri}

Erol Sayan (1936- -) Suzidilara makamını kendi tarif ettiği şekilde kullanmıştır. Sayan'ın "Uydum Kaderin Hükmüne" adlı eseri incelendiğinde bestekârın Mahur ve Çargâh makamı dizilerini kullandığı görülmektedir.

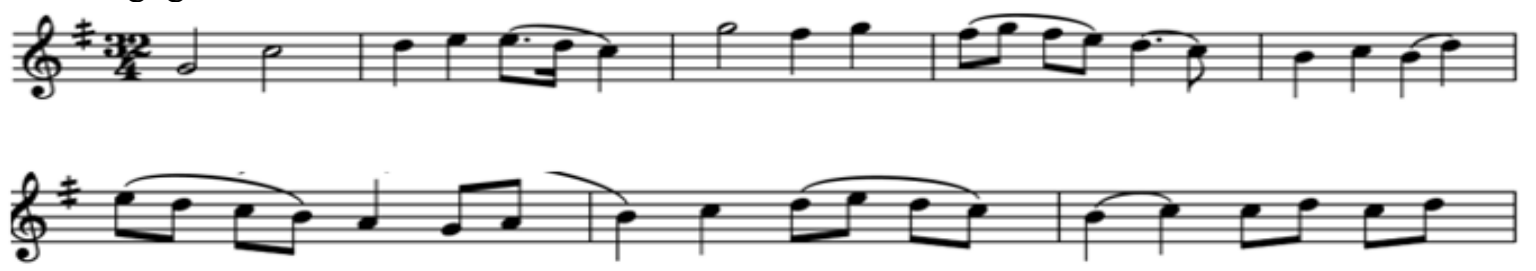

Şekil 40. "Uydum Kaderin Hükmüne” Adlı Eserden Bir Kısım (www.divan.com, 2019).

Birinci ve beşinci ölçü arası: $B u$ ölçüleri incelediğimizde Rast (sol) perdesi üzerinde kurulan Çargâh makamı dizisini, Çargâh (do) perdesi üzerinde Çargâh dörtlüsü ve Bûselik (si) perdesi üzerinde Kûrdi dörtlüsünün kullanıldığını görülmektedir. Altıncı ve sekizinci ölçü arası: Bu ölçüleri incelediğimizde Dügâh (la) perdesi üzerinde kurulan inici Bûselik beşlisi, Çargâh (do) perdesi üzerinde Çargâh dörtlüsü ve Bûselik (si) perdesi üzerinde Kûrdi dörtlüsünün kullanıldığını görülmektedir.

\subsubsection{2. Şeref Çakar’ın “Suzidilara Saz Semaisi” Adlı Eseri}

Şeref Çakar (?) Suzidilara makamını Hüseyin Saadettin Arel'in makamı tarif ettiği şekliyle kullanmıştır. "Suzidilara Saz Semaisi”" eserinin tamamı incelendiğinde bestekârın Mahur ve Çargâh makamı dizilerini kullandığı görülmektedir. 


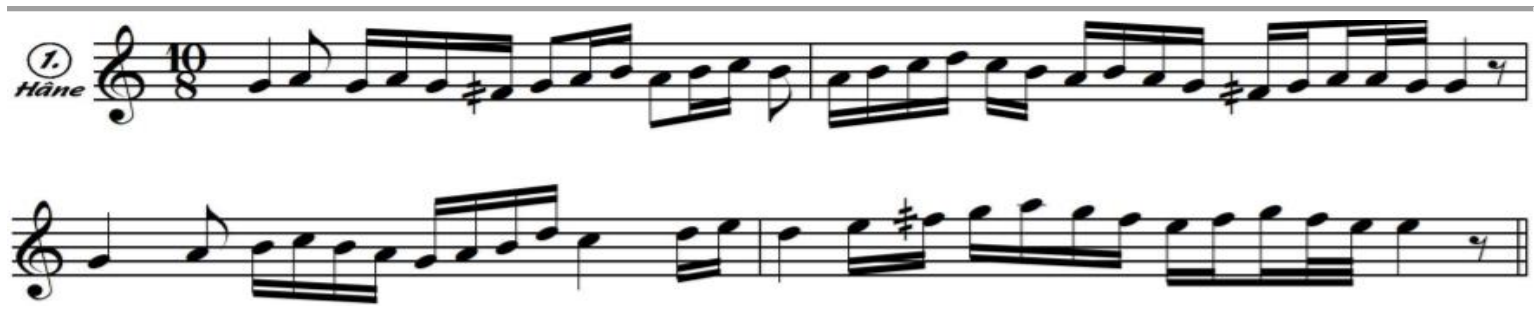

Şekil 41. "Suzidilara Saz Semaisi” Birinci Hane (www.neyzen.com, 2019).

Birinci ölçü: Rast (sol) perdesi üzerinde Çargâh beşlisinin ilk dört sesinin kullanıldığı görülmektedir. İkinci ölçü: Dügâh (la) perdesinde Bûselik ve Rast (sol) perdesinde Çargâh dörtlüsünün kullanıldığı görülmektedir. Üçüncü ölçü: Rast (sol) perdesi üzerinde Çargâh beşlisinin kullanıldığı görülmektedir. Dördüncü ölçü: Neva (re) perdesi üzerinde Çargâh dörtlüsünün kullanıldığı ve Hüseyni (mi) perdesinde Kûrdi dörtlüsü ile yarım kalış yapıldığ 1 görülmektedir.

\section{Sonuç ve Öneriler}

\section{Birinci Alt Probleme Yönelik Sonuçlar}

Bu çalışmada Suzidilara makamı hakkında görüş bildiren 10 kuramcının tarifleri ele alınmış ve bu inceleme neticesinde Suzidilara makamı tarifinde dizi kullanımıyla ilgili üç ana görüş olduğu tespit edilmiştir. Bu görüşler; Çargâh ve Mahur bileşimi ekseninde görüş bildiren kuramcılar, Nigar ve Büzürk bileșimi ekseninde görüş bildiren kuramcilar ve Rast, Buselik ve Hüseyni bileșimi ekseninde görüş bildiren kuramcılardır. $\mathrm{Bu}$ görüşler birbirleriyle tamamen örtüşen görüşler olmamakla beraber temel dizi ile bir araya gelen diğer diziler ve tarif etme şekillerinde bu anlayışların yakın olduğu görülmüştür.

\section{Çargâh ve Mahur Bileşimi Ekseninde Görüş Bildiren Kuramcılar}

Hüseyin Sadeddin Arel ile görüşünü destekleyen Onur Akdoğu, Erol Sayan ve Ahmet Selim Teymur gibi tanınan nazariyatçılar makamın dizi tarifini şu yönde yorumlamıștır; Suzidilara makamının, yerinde Çargâh makamı dizisine Rast perdesindeki Çargâh makamı (Mahur makamı) dizisinin karıştırılmasıyla meydana gelmiştir. İsmail Hakkı Özkan ise makam dizisini tarif ederken Arel'in görüşlerini yorumlamıştır. Suzidilara makamının Batı müziğinde Do Majör ve Sol Majör'den oluştuğunu ve asma kalışlarının ise La minör, Mi minör, Fa Majör ve Re minör olduğunu dile getirmektedir. Makamda bestelenen eserler ile bu anlayıș arasında farklılıklar bulunmaktadır. Çünkü eserlerde Çargâh makamı dizisi belirgin olarak kullanılmamıştır. Makamı oluşturan dizilerin içinde her ne kadar Mahur makamı dizisi sık kullanılsa da Hüseyni perdesindeki Uşşak çeşnisi ve Bûselik makamı dizisi de sık sık kullanılmıştır. Büzürk makamı dizisini andıran bir yapı söz konusudur.

\section{Nigar ve Büzürk Bileşimi Ekseninde Görüş Bildiren Kuramcılar}

Dr. Suphi Ezgi, Suzidilara makamının Büzürk ve Nigar makamlarının devamı olduğunu işaret etmektedir. Sultan III. Selim döneminden önce bestelenen eserler bu görüşü desteklemektedir. $\mathrm{Bu}$ görüşe yakın araştırmacı Nail Yavuzoğlu, Büzürk ve Suzidilara'nın Nigar makamından oluştuğunu dile getirirken Suzidilara makamı dizisinin ise Nigar, Mahur ve Bûselik makamı dizilerinin bir araya gelmesiyle meydana geldiğini dile getirmiştir. Yakup Fikret Kutluğ ise makam dizisinin Nigar, Mahur ve Hüseyni makamı dizilerinin bir araya gelmesiyle oluştuğunu dile getirerek Ezgi'nin makam tarifine yakın bir görüş bildirmiștir. Eserlerin makamsal analizi neticesinde makamı oluşturan dizilerin bu görüş ile örtüştüğü görülmektedir. Kutluğ dizi tarifi yaparken Hüseyni makamı dizisi yerine Hüseyni makamının tiz bölgesi tanımlaması yapmaktadır.

\section{Rast, Buselik ve Hüseyni Bileșimi Ekseninde Görüş Bildiren Kuramcılar}

Ekrem Karadeniz ve Gülçin Yahya Kaçar, Suzidilara makamı dizisini şöyle tarif etmektedir; Rast, Bûselik ve Hüseyni makamlarının bir araya gelmesiyle oluşmuştur. Eldeki eserler 
incelendiğinde Rast makamı dizisi bir eser dışında neredeyse hiç kullanılmamıştır. Yalnızca Cinuçen Tanrıkorur Rast makamı dizisiyle eser bestelenmiştir. Bûselik makamı dizisi ve Hüseyni perdesinde Uşşak dörtlüsü sık sık kullanılmıştır.

\section{İkinci Alt Probleme Yönelik Sonuçlar}

Çalışmada 52 eser incelenmiştir. Bu inceleme sonucu Suzidilara makamının oluşumunda Nigar, Büzürk ve Bûselik bileşimi, Büzürk ve Bûselik bileşimi, Mahur, Büzürk ve Bûselik bileşimi, Mahur ve Bûselik bileşimi Mahur ve Rast bileşimi Rast ve Hüseyni bileşimi ve Mahur ve Çargâh bileşimi dizilerinin kullanıldığı saptanmıştır.

Nigar, Büzürk ve Bûselik dizilerini kullanan bestekârlar; Gazi Giray Han ve Kantemiroğlu'dur. Suzidilara makamında bu anlayışla yazılan 4 eser incelendiğinde ortaya çıkan sonuç şöyledir; Suzidilara dizisini oluşturan makamlar Nigar, Büzürk ve Bûselik'tir. Bu makam dizilerinin bir araya gelmesiyle Suzidilara makamının dizisi oluştuğu gözlenmiştir.

Büzürk ve Bûselik dizilerini kullanan bestekârlar; Raftâr Kalfa, Bülbüloğlu, Seyit Ahmet Ağa, Dellalzâde, Selim Dede, Nâyî Raşit Efendi, Alâeddin Yavaşça, Şehzâde Abdullah ve Manok Ağa'dır. Bu anlayışta 13 (on üç) eser verilmişsir. Suzidilara makamında besteledikleri eserler incelendiğinde makamı oluşturan dizilere dair ortaya çıkan sonuç şöyledir; Büzürk ve Bûselik makamı dizisi bir araya gelmesiyle Suzidilara makamı dizisi oluşmuştur.

Mahur, Büzürk ve Bûselik makam dizilerini kullanan bestekârlar; Sultan III. Selim, Sultan Mehmet Vahdettin, Zekai Dede, Hafiz Mehmet Efendi, Muallim İsmail Hakkı Bey, Fethi Karamahmudoğlu ve Sultan II. Mahmut'tur. Bu anlayışta 18 (on sekiz) eser verilmiştir. Bu bestekârlara göre makamın işleniş biçimi ve kullanımı şöyledir; Mahur, Büzürk ve Bûselik makamı dizilerinin bir araya gelmesiyle Suzidilara makamı dizisi meydana gelmiştir.

Mahur ve Bûselik dizilerini kullanan bestekârlar; Arapzâde, Kemani Rıza Efendi, Cemil Bey, Udi Hasan Bey, Necdet Varol, Akın Özkan ve Sitkı Sahil'dir. Bu anlayışta 7 (yedi) eser verilmiştir. Bu bestekârlara göre Suzidilara makamı dizisi Mahur ve Bûselik makamı dizilerinin bir araya gelmesiyle oluşmuştur.

Rast ve Hüseyni makamı dizilerini kullanan bestekâr; Cinuçen Tanrıkorur' dur. Bu anlayışta 1 (bir) eser verilmiştir. Bestekârın eseri incelendiğinde Rast ve Hüseyni makamı dizilerinin bir araya gelmesiyle Suzidilara makamı dizisinin oluştuğu görülmektedir.

Mahur ve Çargâh makamı dizileri kullanan bestekârlar; Erol Sayan, Şeref Çakar, Varujan Zilciyan, Sadettin Çevik, H. Hüsnü Üstün ve Yalçın Mıhçı'dır. Bu anlayışta 7 (yedi) eser verilmiştir. $\mathrm{Bu}$ anlayışa göre Suzidilara makamı dizisi Mahur ve Çargah makamı dizilerinin bir araya gelmesiyle oluşmuştur. Bu bestekârların Arel anlayışını yansıttığı görülmektedir.

\section{Öneriler}

Geleneksel Türk müziğinde makam, tarif ve özellikleri bakımından incelediğinde nazari farklılıklar göze çarpmaktadır. Bu konuda çalışma yapmak isteyen araştırmacıların mutlaka birden fazla nazari kaynağı incelemeleri gereklidir. Bununla birlikte aynı makamda bestelenmiş eserlerin ezgisel analizinin yapılmasının sağlıklı bir sonuca götüreceği düşünülmektedir.

Makamsal eser analizi yapılırken makamda sınırlı sayıda eserin analiz edilmesi doğru bir sonuca götürmeyebilir. Sağlıklı bir sonuca ulaşabilmek için incelenecek olan makamda bestelenmiş bütün eserlerin incelenmesi gerekmektedir. Bütün eserlerin incelenmesi mümkün olmayan durumlarda ise bestekârların eserleri sınırlanması doğru bir bakış açısı kazandıracaktır. 


\section{Kaynakça}

Ak, A. Ş. (2014). Türk Musikisi Tarihi (İkinci b.). Ankara: Akçağ Yayınları.

Akdoğu, O. (1993). Hüseyin Sâadeddin AREL 'Türk Mûsıkîsi Nazariyatı Dersleri”' (Birinci b.). Ankara: Kültür Bakanlığı Yayınlar Dairesi Başkanlığı.

Akdoğu, O. (1996). Türler ve Biçimler (Birinci b.). İzmir: Ege Üniversitesi Basımevi.

Arslan, F. (2014). Müslüman-Türk Bilginlerin Müzik Bilimine Katkıları (X-XIII. Yüzy1llar). Türkiyat Mecmuası, 24(2), 1-21.

Can, M. C. (2002). Geleneksel Türk Sanat Müziğinde Arel-Ezgi-Uzdilek Ses Sistemi ve Uygulamada Kullanılmayan Bazı Perdeler. Gazi Üniversitesi Gazi Eğitim Fakültesi Dergisi, 22(1), 175181.

Ezgi, M. S. (1933). Nazari ve Ameli Türk Musıkisi (Birinci B.). İstanbul: Milli Mecmua Matbaas1

Gurbetoğlu, A. (26, 02 2018). Bilimsel Araştırma Yöntemleri. agurbetoğlu.com: http://agurbetoglu.com/files/2\%20ARA\%C5\%9ETIRMA\%20\%20T\%C3\%9CRLER\%C4 \%B0.pdf adresinden alındı (erişim tarihi 10/06/2019).

Kaçar, G. Y. (2008). Türk Mûsikîsinde Makam. istem • Yll:6 (11), 147-148.

Karadeniz, M. E. (2013). Türk Mûsikîsinin Nazariye ve Esasları (Birinci b.). İstanbul: Türkiye İş Bankası Kültür Yayınları.

Koç, F. (2011). Sultan III. Selim Han'ın Terkip Ettiği Türk Müziği Makamlarının İncelenmesi. Ankara Üniversitesi Sosyal Bilimler Enstitüsü Dergisi(2,(2)), 92-93.

Koç, F. (2003). Sultan III. Selim Han'ın Mûsikî Eserlerinin Müzikal Analizi. Yüksek Lisans Tezi, Marmara Üniversitesi, Sosyal Bilimler Enstitüsü. İstanbul.

Kutluğ, Y. F. (2000). Türk Müziğinde Makamlar (Birinci b.). İstanbul: Yap1 Kredi Yayınları.

Nota Arşivleri, Türk Sanat Müziği Nota Arşivi. https://www.notaarsivleri.com/: https://www.notaarsivleri.com/arama.html?kelime=suzidilara adresinden alındı (erişim tarihi 03/12/2018)

Nota Arşivleri Klasik Eserler NotaArşivleri. https://www.neyzen.com/: https://www.neyzen.com/makamlar/suzidilara.html adresinden alındı (erişim tarihi $15 / 12 / 2018)$.

Nota Arşivleri. https://divanmakam.com: https://divanmakam.com/_forum_/eser-nota-arsivi.4/. adresinden alındı (erişim tarihi 26/11/2018)

Oransay, G. (1973). Cumhuriyetin İlk Elli Yılında Geleneksel Sanat Müziğimiz (Birinci b.). Ankara: Ankara Üniversitesi İlahiyat Yayınları.

Özkan, İ. H. (2000). Türk Mûsıkîsi Nazariyatı ve Usûlleri Kudüm Velveleleri (Altıncı b.). İstanbu: Ötüken Neşriyat A.Ş.

Salgar, M. F. (2005). 50 Türk Müziği Bestekârı (Birinci b.). İstanbul: Ötüken Neşriyat A.Ş.

Salgar, M. F. (2017). Türk Müziğinde Makamlar / Usûller ve Seyir Örnekleri (Birinci b.). İstanbul: Ötüken Neşriyat A.Ş.

Sayan E. (2010). Ulusal Müziğimiz (Birinci b.). İstanbul: Boyut Yayın Grubu 
Şenoğlu, S. (1994). IVIII Yüzyll Bestekârı Vardakosta Ahmet Ağa'nın Türk Musikisindeki Yeri ve Önemi. Yüksek Lisans Tezi, İstanbul Teknik Üniversitesi, Sosyal Bilimler Enstitüsü. İstanbul.

Teymur, A. S. (2010). Türk Musikisi (Birinci b.). İstanbul: Pan Yayınc1lık.

Tura, Y. (2006). Nasır Abdulbâkî Dede "Inceleme ve Gerçeği Araştırma (Tedkîk ü Tahkîk (Birinci b.). İstanbul: Pan Yayıncilik.

Tura, Y. (2017). Türk Musıkisinin Mes'eleleri (Birinci b.). İstanbul: İz Yayıncılık.

Uruş, N. D. (2012). Meşk İle İntikalde Müzik Eseri: III. Selim'in Suzidilara Mevlevi Ayini. Internatıonal Journal Of Human Sciences (9,2), 428-429. alınd1 (erişim tarihi 23/01/2019)

Uzun, M.İ. https://islamansiklopedisi.org.tr/gazi-giray-ii\#2 adresinden alındı erişim 10/02/2020

Yarman, O. (2010). Nazariya ve Teknik Boyutuyla Ses Dünyamızda Yeni Ufuklar (Birinci b.). İstanbul: Artes Yayınları.

Yazvuzoğlu, N. (2011). Türk Müziğinde Makamlar ve Seyir Özellikleri (İkinci b.). İstanbul: Pan Yayınc1lik. 